University at Buffalo School of Law

Digital Commons @ University at Buffalo School of Law

2008

\title{
Law and Economic Change During the Short Twentieth Century
}

John Henry Schlegel

University at Buffalo School of Law, schlegel@buffalo.edu

Follow this and additional works at: https://digitalcommons.law.buffalo.edu/book_sections

Part of the Economics Commons, Law and Society Commons, and the Legal History Commons

\section{Recommended Citation}

John Henry Schlegel, Law and Economic Change During the Short Twentieth Century in Cambridge History of Law in America 563 (Michael Grossberg \& Christopher Tomlins, eds., Cambridge University Press 2008)

This material has been published in Cambridge History of Law in America edited by Michael Grossberg \& Christopher Tomlins. This version is free to view and download for personal use only. Not for re-distribution, re-sale or use in derivative works. (C)ambridge University Press 2008.

\section{C. ${ }_{\text {COPYRIGHT }}^{\text {N }}$}

This Book is brought to you for free and open access by the Faculty Scholarship at Digital Commons @ University at Buffalo School of Law. It has been accepted for inclusion in Contributions to Books by an authorized administrator of Digital Commons @ University at Buffalo School of Law. For more information, please contact lawscholar@buffalo.edu. 


\title{
LAW AND ECONOMIC CHANGE DURING THE SHORT TWENTIETH CENTURY
}

\author{
JOHN HENRY SCHLEGEL
}

At the beginning of the short twentieth century heavy, blue-collar industry dominated the physical economy. Railroads were the dominant form of continental transportation; the ocean liner (for passengers) and the freighter (for cargo) the only available form of intercontinental transportation. Radio was the new, wonderful, transformative industry, and national consumer brands were beginning their domination of the grocery store's growing cornucopia.

At the end of the century, service industries dominate the economy. Were there any notion of the physical economy, it would probably focus on multiple kinds of imported consumer goods. Continental transportation of goods is dominated by interstate trucking; that of passengers, by airplanes. The ocean liner has changed into a floating hotel called the cruise ship; intercontinental passengers travel by air and goods in large steel boxes on truly ungainly looking, specially designed container ships. The Internet qualifies as the new, wonderful, transformative industry, and produce from Latin America has begun to dominate the grocery store's still expanding bounty.

Looked at in a more schematic way, the story is the same. During years that witnessed an amazing growth in the administrative apparatus of all levels of government, there simultaneously occurred three large-scale changes, three of those developments that somehow define eras. First, the middle class expanded to include a portion of the working class as part of a dominating consumer culture. Second, the imperial Northeastern manufacturing economy, the colonial Southern agricultural economy, and the colonial Western agricultural and natural resources economy all declined while simultaneously a lighter manufacturing economy in the South and West grew, as did a service economy throughout the country. And third, the American island economy that followed World War II declined as a significantly more international economy of manufacturing, finance, and, to a lesser extent, agriculture and natural resources took shape. 
Surely then, these years have seen profound economic change. Yet in some ways, a concomitant change in the way that the economy is experienced, structured, thought of is equally important. At the beginning of the short twentieth century the model of a good economy was one in which groups of manufacturers or retailers believed that, by associating together with the objective of treating each other fairly, a high-price, high- wage economy could deliver prosperity for all. And during the Depression the federal government put into place a legal framework that could support such an associationalist economy. But by the end of that century, such a model was of interest only to historians. Its obliteration was so complete that many advocates of unionized labor had little understanding of how their language of fairness tied into a lost economic model dependent on local and regional oligopolistic conduct. In place of that model we now have a new one, based on atomized and decentralized production tied together with round-theclock instantaneous communication and with financial structures favoring very short time horizons, that has for its hallmark a collective obsession with speedy flexibility.

What significance can we ascribe to law - by which I mean the many and variable actions undertaken by lawyers and other governmental officials, the formal and effective norms originating from the practices of these individuals, and the systematic presuppositions shared among them - in the extraordinary story of economic change that is the short twentieth century? I wish to argue that, properly understood, the answer to this question is "very little," though a not unimportant "very little." In so arguing, I am not to be understood as embracing either of the following perspectives on the general relationship of law and economy. First, law is not simply a prisoner of the market forces of a time and place. Nor, second, is it irrelevant except to the extent that it unwisely attempts to constrain market actors from pursuing their selfinterest. Rather, the pervasiveness of law in structuring the economy of this and any other set of years is or ought to be obvious to all but the most unreflective Marxist or vulgar free marketeer. Indeed, I would go so far as to assert that, at any given time and place, price - the efficient market solution to a question of demand and supply - is fully determined by law, seen as a set of legal entitlements, together with the set of resource endowments distributed among economic actors at that time and place. Moreover, any significant alteration in those legal entitlements will cause an alteration in that efficient market solution. However, questions about such, almost static equilibriums are not my concern here. Instead, I wish to talk about change, about movement from one economy to another.

Then what do I mean by "an economy?" An economy, a persistent market structure, is the fusion of an understanding of economic life with the patterns of behavior within the economic, political, and social institutions that enact that 
understanding. Law contributes pervasively to any such understanding; it affirms, structures or restructures, and so, in an obviously separable sense, enacts, the relevant institutions that economic actors use when buying and selling, working and investing, as part of their daily life. But questions of economic change are not answered by summing all of the activities, including legal change, that make up daily economic life. Economic change is the shift from one enacted (in both senses) understanding of economic life to another - in the case of the short twentieth century, from an associationalist economy to what I call an impatient economy. In this chapter I hope first to explicate this economic change, and then to interrogate it in order to understand the role of law in its occurrence. ${ }^{\mathrm{I}}$

\section{THE TWENTIES AND THIRTIES: AN ASSOCIATIONALIST} IDEAL

At the end of World War I, the United States, which had just completed an extraordinary period of industrial expansion followed by one of industrial concentration, was the largest national economy in the world. Its greatest strength, aside from a substantial natural resource base, was its enormous domestic market tied together by a strong railroad network that allowed the country to be a relatively insolated, self-sufficient economic entity. This is not to say that the United States did not participate in international trade and finance. It was a key player in both areas. Rather, the size of the domestic market and its relative affluence meant that most manufacturers and many retailers had a market so large that they could grow to an enormous size based on transactions within the domestic economy alone, protected, of course, from foreign competition by relatively high trade barriers.

Given these obvious advantages, the economy's overall performance in the following two decades was surprisingly erratic, but overall disastrously weak. A sharp postwar inflationary spurt was followed first by an equally

\footnotetext{
${ }^{\mathrm{I}} \mathrm{A}$ word about periodization is in order. I take the twenties to extend from the end of the postwar demobilization - about I9I9- until the stock market crash in I929. The thirties is a long period continuing until I94 I when, with the adoption of Lend-Lease, the U.S. economy was placed on a wartime footing. The forties extend only to I 947 , the end of the post-war inflation. Then came the fifties. The sixties begin late - in I962 and end with the rise in oil prices that accompanied the Yom Kippur War in I973. The seventies continue until the onset of the Reagan administration in I98 I or maybe until inflation finally turns down in the wake of the terrible recession of I982. The eighties begin thereafter or possibly in 1979 when the Federal Reserve Board moved to contract the money supply sharply, and last until the end of the recession just before the start of the Clinton administration, that is the nineties. These are, I must emphasize, economic periods; I would identify social periods quite differently.
} 
sharp recession and then by a somewhat frenetic period of genuine growth. Thereafter, a general recession that began just slightly before the famous stock market crash of October 1929 terminated a classic market bubble turned serious - turned into the Depression. Four years later, when the economy bottomed out, the unemployment rate was about 25 percent; prices, particularly of farm products, had declined significantly; mortgage foreclosures had hit record levels, as had bank failures; and not surprisingly, industrial production had plummeted as well. For the balance of the decade the economy grew slowly, interrupted only by a decline in 1937 , though not to the level of its pre-Depression high.

If one factors out the substantial amount of noise in the economic record of these years, several significant changes stand out. The most obvious is the growth of an extensive consumer electric (though surely not electronic) appliance industry led by radios, irons, vacuum cleaners, and to a much lesser extent refrigerators, as electrical service was extended to most urban and increasing numbers of rural households. Equally noticeable was the great expansion in automobile ownership, though here the impact of this growth was more significant in rural areas, where auto ownership provided a significant opportunity to reduce isolation, than in urban ones, where existing transit networks and shops within walking distance made the cost of ownership seem more of a barrier to purchase.

More invisible, but in the long run equally significant, were two changes. The first was the slow development of the commercial aircraft industry whose major success with the DC- 3 began the increase in air travel in the late thirties. The second was the expansion of consumer services, especially in the twenties, both in the financial area, with the growth of installment purchase of autos and appliances, and in retail trades of all kinds. Nevertheless, the economy of the Northeast still was dominated by heavy industrial production, such as steel, autos, and electrical machinery, and by rail transport, all of which employed enormous numbers of blue-collar, variously skilled workers, pretty much in accordance with late-nineteenth-century industrial norms. The South was still largely an agricultural economy and the West an agricultural and mining economy. Both thus provided lowvalue goods to feed Northeastern factories and mouths. The whole was stitched together with a railroad system that had reached its peak size just before the Great War and had begun to shrink in size thereafter.

With immigration cut off, the ethnic makeup of the population was largely settled; immigrants and their families from Eastern and Southern Europe provided much of the workforce in the large industrial plants. This was the backbone of the working class. Northern Europeans provided much of the white-collar workforce, staff and line, that ran the predominantly dispersed, divisional structure of large industrial corporations. These 
individuals were the dominant element in the middle and lower middle class that had come numerically to overwhelm the upper middle class of professionals and local owners of shops and small factories. At the same time, the growth of line functions in large industrial corporations and of service industries brought an increase in female, particularly unmarried female, waged labor, beyond the traditional work in textiles and apparel.

Such a structure to the economy was not wholly surprising, given the persistence of the remains of the large turn-of-the-century industry-specific mergers designed to create effective product monopolies. The surviving firms had, as a result of effective antitrust intervention during the Taft and Wilson administrations, devolved into relatively stable oligopolies that tended both to maintain their production processes and to grow vertically so as to control supplies and distribution. At the same time, "discounters" or "chain stores" - national retail organizations such as the Great Atlantic \& Pacific Tea Company (the A \& P), Sears, Roebuck \& Co., or Montgomery, Ward \& Company - began to establish branches in order to infiltrate local retailing markets that previously were effectively insulated from competition by the still significant difficulties of greater than local passenger transportation. The simultaneous growth of distribution through nationally controlled, locally franchised retailing organizations caused much consternation to local elites unused to more than incidental competition at the retail level. As a result, these local elites began to utter the same variety of complaints about ruinous or destructive competition and predatory pricing that had been voiced by those large manufacturers who sought refuge in the great merger movement twenty-five years earlier. These complaints, which continued to be heard from producers in such more competitive industrial segments such as lumber, coal, and cement, coalesced in a movement that is commonly called associationalism.

Many economic theorists who supported associationalism in the twenties and thirties believed that economic instability was the result of excess production of goods and services coupled with relentless downward pressure on producer prices caused by "chiselers" who reduced prices and otherwise "cut corners" for temporary personal advantage. These economists argued that downward pressure on prices could be resisted if producers banded together into groups that would work both to "coordinate" production (i.e., manage reduction and expansion) and to isolate and vilify chiselers, so as to enforce good - and thereby suppress "unfair" - trade practices. This theory also held that insufficient demand in poor times could be remedied by increasing employment and by providing Social Security and unemployment insurance so that the disposable income of wage earners, and thus demand, could be maintained: a Keynesian prescription before John Maynard Keynes produced his famous volume. 
Associationalism was essentially a Main Street, though not therefore a small town, theory. It hoped to maintain high wages through the high prices that would support the small, local retail or wholesale businesses that were being undercut by the growth of large regional or national retailers, as well as the more competitive sectors of the producer economy. This design was for an economy of uniform, high prices, such as that found in more oligopolistic markets or as was enshrined in the steel industry's basing-point price system whereby all steel prices were quoted as if the product were being shipped from Pittsburgh. It denied distant local producers locational monopoly pricing ability, but at the same time allowed them to make up in freight charges collected, but not incurred, the costs associated with their smaller scale, and so higher cost, production processes.

Not laissez-faire in a different guise, associationalism assumed some level of governmental involvement in the economy, as befits a theory whose public champion was Herbert Hoover, first as Secretary of Commerce under both Harding and Coolidge and then as president. Supported by the Federal Trade Commission, the theory received and required a crabbed construction of the antitrust laws so as to permit associations to perform their regulatory and disciplinary functions, as well as some legal support for suppressing unfair trade practices. It also seemed to require high trade protection for American industries, and indeed, these ideas are popularly associated with the Smoot-Hawley Tariff of I930. When reduced to legislation, associationalism regularly echoed Progressive concerns about the protection of small producers and ordinary workers, as can be seen in the "first" New Deal of the Roosevelt administration, in which associationalism spawned the National Recovery Act and the Agricultural Adjustment Act, as well as such seemingly unrelated legislation as the Social Security Act, the Wagner Act, the Fair Labor Standards Act, the Federal Housing Act, and the Robinson-Patman Act. The prevalence of agricultural marketing cooperatives and state retail price maintenance statutes are of a piece. Surviving bits of the self-regulatory norm inherent in the theory still can be found in the New York Stock Exchange, the National Association of Securities Dealers, and the numerous bodies setting industry standards that exist in fields such as plumbing and electrical equipment. The theory can even be seen in Karl Llewellyn's early plans for the sales article of the Uniform Commercial Code.

The accuracy of the associationalist diagnosis of the problems of business in the twenties and thirties is, for present purposes, unimportant. Accurate or not, the managed, associationalist market was a prominent economic ideal in the years between the wars. However, that ideal had another side to it. Stabilization of prices at high levels and control over the introduction 
of innovation protected the market position of large producers as well as small retailers. For such producers, the theory could be seen as justifying classic cartel behavior, behavior that in Europe led to collusion with large trades' unions and to industry-wide bargaining, still epitomized by the metalworkers union in Germany. In the United States this variation on the cartel model supported the relatively static competitive position of participants in the more oligopolistic markets. Under oligopolistic competition, leading firms in effect negotiated price publicly and then strove to avoid undercutting that price. Simultaneously, they used their research staffs and advertising to generate product differentiation that might alter market share in their favor, always dreading the possibility that a competitor would develop a "breakthrough" product that could remake current, reasonably stable relationships in unforeseen ways.

Although associationalism as a theory clearly preferred the private organization of markets implicit in the ideal of an association, it just as clearly recognized that stable economic relationships that yielded high prices, high wages, and continuous profits could be established by governmental regulation. Thus, it could support a regulatory response to the widely felt sense that a weak and speculative financial system was a contributor to the Depression. The extension of speculative credit, especially in the real property and securities markets, was viewed as "unfair," as were widespread selfdealing, manipulation, and even fraud in bank lending practices and in the underwriting of securities issues and their trading in the stock market. The response at the federal level was the creation of significant federal legislation directed at boosting confidence in the financial system. The Glass-Steagall Act (Banking Act of 1933), requiring a separation of commercial from investment banking, and the legislation establishing the Federal Deposit Insurance Corporation, Federal Savings and Loan Insurance Corporation, Federal Home Loan Bank Board, and the Federal Farm Credit Administration were each designed to increase the soundness of the banking system by creating the stable, profitable relationships among the providers of a major source of credit for the economy that were favored by associationalism's theorists. The legislation establishing the Securities Exchange Commission and securing for it the means for regulating the securities markets based on a principle of disclosure and of penalties for non-disclosure, including the Securities Act of 1933, the Securities Exchange Act of 1934, the Investment Company Act, and the Trust Indenture Act, was structured similarly. Together such legislation was designed to strengthen those institutions essential for the credit and investment expansion that would undergird recovery, and, not incidentally, honestly finance both oligopolistic producers and Main Street merchants. 


\section{Law and Economic Change: An Initial Interrogation}

This brief recounting of the American economy in the twenties and thirties raises obvious questions about law and economic change. As one lists even a small part of the New Deal's legislation, one can quickly identify the response of law to economic dislocation. Local relief efforts were supplemented with funds supplied by federal programs mounted by the Works Progress Administration and the Civilian Conservation Corps, programs that are largely lost in any brief telling of the story of the economy in these years, but crucial for those whose hunger they reduced and shelter they supported. The great structural statutes in agriculture, banking, communications, labor, securities, and transportation that survived Supreme Court challenge, as well as those that did not - the National Recovery Act (NRA) and Agricultural Adjustment Act (AAA) - also exemplify the way that law is regularly mobilized in times of trouble. All were significant changes in the doctrinal matrix that is the law at a time and place. They can even be seen to have significantly aided the creation of the administrative state. But that said, the role that these statutes played in economic change remains unclear.

Each changed the efficient market solution to a problem of supply and demand; that much is clear. Consider only two modest changes - the Fair Labor Standards Act and the Trust Indenture Act. Both were classic associationalist pieces of legislation based on its diagnosis of under-consumption as the root of economic weakness and its penchant for picking up on unfinished Progressive causes. The first created the rule requiring time-and-ahalf for overtime for certain groups of workers. After adoption it could be expected that such a rule would, at the margin, make employers respond to the opportunity to increase production by relying less on extending the hours of existing workers and more on increasing total employment. At the same time, the Fair Labor Standards Act's adoption of a firm rule worked toward minimizing the old problem of whether employers unfairly coerced employees to work long hours. The Trust Indenture Act yoked old problems even more directly to new objectives by establishing rules dictating "fairer" terms in the indentures that governed bond issues with respect to trustee selection, notice to bondholders, and their consent to the restructuring of bond obligations. Such statutory provisions were expected, again at the margin, to increase the willingness of investors to purchase bonds because they knew that their interests were better protected. However, the change in the efficient market solution to a problem of supply and demand at a hypothetical margin is like a tree falling in the forest unheard. Unless that margin is reached, legal change changes nothing in the economy. What passage of the law means is that a set of structures have been put into place 
that may or may not become relevant under future economic conditions, dependent as they are on future political, technological, even demographic occurrences.

But to notice the structural element in such legislation is to bring to the forefront the matter of the degree to which the New Deal statutory reforms enacted the associationalist economy. Here the answer is a resolute negative. The creation of potentially efficacious institutional structures is not enough to "enact" an economy. Consider the possibility that, contrary to fact, World War II had ended with a long-term truce among four or five countries whose manufacturing capacity remained in good shape and so whose economies competed vigorously. There is little reason to believe that in such circumstances, circumstances in which relative insulation from the world economy would decrease as air and ocean transportation improved, the margin where any of these statutes would bite would ever be reached. These laws might well have been of antiquarian interest, but little else. Indeed, their notoriety today is a function of the fact that at some point action within the institutions that they created actually took place, that the economic relations that they made possible came to pass.

Note, however, that even though a change of behavior at the margin may never take place, a change in legal entitlements may easily work a change in the distribution of economic resources. The Fair Labor Standards Act immediately made some employees wealthier, those whose wage gains were less than the cost of hiring additional employees, especially where slack demand or capacity constraints effectively turned the choice to hire additional employees into the choice to begin a second shift. And this increase in disposable income of individual workers may well have been enough to alter, as always at the margin, the efficient market solution to other questions of supply and demand, most obviously those of clothing, food, and housing. But such an alteration is no more a change in an economy than would be the modest change in the market for legal services brought on by adoption of the Trust Indenture Act. Law changes lots of things in the details of economic life for the participants without bringing about a transformation of the economy from one enacted understanding of economic life to another.

\section{THE FORTIES AND FIFTIES: ASSOCIATIONALISM AT WORK}

Wartime mobilization and then production pulled the economy out of the Depression in ways that all the thinking and writing of economists and all the action of politicians could not manage. By taxing some, borrowing much, and spending it all to win the war, the United States adopted a Keynesian solution to its economic problems, but out of necessity, not out 
of theoretical understanding, for such a theoretical solution was still rejected by most economists, as it had been during the Depression.

Total war meant that there were jobs for virtually everyone not actively engaged in the armed forces. However, the rationing and price controlling of most consumer products, combined with the termination of production of other products, meant that wartime wages were, by default, largely saved. The technological innovations that the war spawned were notable synthetic rubber, radar, sonar, separation of uranium isotopes using the hexafluoride compound, and the vacuum-tube-dependent ENIAC computerbut changed the lives of Americans very little during those years. Much more significant was the wartime spread of military installations and, to a lesser extent, war production plants, in the South and West that over time began to break the agriculturally based colonial economy of the former and the natural resources and agriculture based colonial economy of the latter.

Wartime economic practice continued to support the associationalist bent of the economic/legal understanding of the period that preceded it. Given the inflationary pressures that came with a sharp growth in total wages and the wartime price control mechanism that was designed to deal with those pressures, the existing structure of commercial relations was, if anything, reinforced. Not only did the large, established firms that secured the greatest portion of war-related contracts prosper, but also firm prices on rationed goods meant that small units of production and distribution prospered as well. The war may not have been won on Main Street, but Main Street prospered as much or more that it had in the very brief euphoria that was the economy of the twenties.

Labor also prospered. Though wage increases were drastically limited under the War Labor Board's fabled "Little Steel formula," at least union recognition and bargaining over working conditions were ensured. Strikes, like wages, were limited, at least in theory. In practice the incidence of strikes increased over the course of the war. However, out of the wartime experience both labor and management started down the road toward understanding that the country preferred industrial peace at a modest price. Acceptable were increased costs from modest wage increases, from the introduction of non-wage benefits, from the recognition of work rules that kept production expensive but labor less onerous (a covert form of a wage increase), and from the proliferation of by law guaranteed time-and-a-half overtime, the major source of increased prosperity for workers.

Overseas, American aircraft were attempting to destroy both European and Japanese industrial might while allied diplomats planned for a postwar international order, efforts that at Dumbarton Oaks led to the creation of the United Nations and at Bretton Woods to the outline of a new economic order. The Bretton Woods agreements reestablished the fixed rate regime for 
foreign exchange that Roosevelt had interred when he took the United States off the gold standard in 1933. Under the Bretton Woods gold exchange standard, the United States agreed to exchange dollars for gold, but only in transactions with foreign central banks, at a rate of $\$ 35$ per ounce. The currencies of the other states that participated in the system were then tied to the dollar or gold at fixed rates, and states agreed to maintain their currency within a band (generally, I percent) of the fixed rate. The International Monetary Fund, also established at Bretton Woods, was designed to lend money to states that had insufficient gold or foreign currency reserves to keep the actual value of their currency at the agreed-on rate, usually because of an inability to cover their trade deficits.

At the end of the war, Europe, even victorious Great Britain, was prostrate with a combination of significant population loss, destruction or exhaustion of industrial plant and equipment, destruction of infrastructure, and removal of captive sources of raw materials. Indeed, the destruction had been so severe that economic conditions throughout the continent were worse in 1947 than they had been in I945. Only with the Communist takeovers of countries in Eastern Europe did economic conditions begin to pick up when, in response, the United States began to pour into Western Europe economic aid under the Marshall Plan and military aid, always a prop to an economy, under NATO. Still, even with all this aid, Europe and comparatively less aided Japan were restarting their economies from a very low level.

In contrast, the United States had won all the marbles. As the only truly functioning major economy north of the equator, it held virtually all economic power in its hands and thought that it held all political power as well. Like Julius Caesar, it bestrode "the narrow world like a Colossus." The returning GIs cared little about such things, however; they needed jobs. Their needs brought about the replacement of women workers with men in many of the best paying jobs, though only a temporary decline in female participation in the waged workforce. The development of an ideology in support of this maneuver exalted the notion of the one-wage-earner family supported by a "family wage." Although the decline of overtime in the immediate post-war years initially made the notion of the family wage quite difficult to achieve, the GI Bill, for a time at least, served to sop up much potential unemployment, with its extension of benefits for servicemen who sought further education, particularly higher education, which the colleges were quick to supply.

Immediately after the war, the rise in consumer demand - fueled first by the simple absence of goods and services during the war, second by the disproportionately large savings that were accumulated in those years when high wages could find few goods to purchase, and finally by the developing 
baby boom - brought significant inflation. But by 1947 inflation subsided, with only a modest spurt in 1950 associated with the onset of the Korean War. Housing and autos then led the postwar economic expansion. In addition, the United States was exporting goods, including farm products, at a very high level. These exports earned large, if not wholly meaningful, trade surpluses; they were financed with aid or credit from the federal government, for there was little that European countries and Japan had to export.

America's military and economic spending in Europe, the same kind that drove the American economy during the war, was modestly helpful in supporting domestic postwar expansion. The reintroduction of wartime production that accompanied the Korean War meant that large-scale government stimulation of the economy returned for the better part of four years; it was accompanied by another dose of somewhat less generous GI Bill benefits. But Korea was not fought under conditions of "total war." This time consumption was not particularly squeezed as a result of war mobilization.

The economy grew strongly during these war years and continued its growth into its next decade. Purchasing power was reasonably stable after I950; capital, reasonably plentiful; consumer goods, everywhere to be found; foreign sales, large. Only agriculture seemed to lag. Farm employment continued its wartime decline; farm size, its wartime increase; farm income, its relative stagnation. This is not to say that in urban areas the great postwar expansion was inexorably upward. Indeed, there were three modest recessions during the chronological fifties, the last coming at the end of the decade and contributing to the election of a Democratic administration in 1960. But these were rightly seen as good years by consumers, wage earners, and businessmen, fueled, as they were, by the insulation of the domestic economy from international competition originating in the still recovering European and Japanese economies and by the interaction of this insulation with the practices of the associationalist legal/economic model of a good economy.

The lack of international competition meant that American industry could raise wages and easily pay for such wage increases by raising prices modestly, relying on increases in demand to lower unit costs, and by deferring improvements in production processes, plant, and equipment. Nor was there any internal need to do otherwise. Industry-wide bargaining meant that competitors were seldom differentially disadvantaged by increases in wages, increases that to some extent may have reflected productivity gains. The prices of non-labor product inputs were reasonably steady, and domestic companies controlled access to most raw materials, particularly petroleum, at low world prices. And stockholders were a quiescent, dispersed lot, as 
Adolph Berle and Gardiner Means had observed a generation earlier, who looked primarily for predictable dividends and less for capital appreciation. Disgruntled investors sold; they did not fight management.

The continued authority of the associationalist ideal of managed, rather than ruinous, competition seemingly protected retail business owners, though here the development of new national chains, such as McDonald's and Holiday Inn, and the expansion of discounting beyond groceries into hard goods ought to have given careful observers pause. And that ideal similarly protected members of the numerous oligopolistic industries by limiting them to "gloves on" competitive fights for market share. American industry had become big, cumbrous, comfortable, and more dependent for its prosperity on the gross level of demand derived from increases in total employment than on product improvement derived from capital investment.

In some ways the quiescent state of American industry in these years is somewhat counterintuitive. At the same time that producers were insulated from international competition to their products, capital costs were unusually low because the United States maintained a sheltered market in credit growing out of the structure that New Deal legislation left behind. Checking account demand deposits were largely limited to corporations and upper- or upper-middle-class families, and there were few equally liquid investments offered elsewhere. Securities were effectively purchased by a similarly limited group, due in part to high and fixed minimum brokerage commissions and in part to a lingering fear of the stock market that many middle-class people had learned from the Great Crash. Savings for most people were channeled into time deposit savings accounts, often at savings and loan associations that were statutorily limited to paying low rates of interest -2 or 3 percent for most of these years - and similarly limited in their investment of these funds to home mortgages, often insured under the FHA or the GI bill. This segmentation of the national pool of savings provided support for the housing markets, as well as a pile of corporate bank balances available for lending to corporate borrowers at rates that were secure from serious competition from the long-term, debt-oriented securities markets.

One might have expected that the relatively low cost of credit would have brought forth a torrent of investment in new product development, old product innovation, and improvement of production processes to make up for the lack of such investment since I929. But this did not happen on a grand scale. Innovation was obvious in the mass production of the primarily suburban, new housing modeled on Levittown and in air conditioning, television, and stereo. But the results of a lack of innovation were also already evident. In iron and steel, little significant investment in new processes 
was made after the Korean War. In rails, new investment was limited to replacing steam with diesel power. This obvious improvement in technology drew attention away from the continuing decline in demand, both in terms of passengers and freight, that the boom in heavy transport during World War II had obscured. Passenger rail travel declined with the proliferation of private autos and later with the growth of business air travel; freight declined with the increasing availability of truck transport, a circumstance obvious even before the war. Indeed, the plans for what became the Eisenhower Interstate Highway System in I957 were first drafted in I94I. At that time the proposal was advanced on precisely the twin grounds successfully offered sixteen years later - national defense and highway congestion from increasing truck traffic.

The social consequence of what in retrospect was a hot-house economy, insulated from competition abroad and limited in competitive pressures at home, was a dramatic increase in the middle class, both white collar and blue. This larger middle class was built on three things: reasonably high wages; low housing costs, aided by the nationwide adoption of the fully amortizable, thirty-year mortgage (introduced on a mass scale by federal agencies during the Depression) available at interest rates intentionally kept low by the structure of banking regulation and effectively lowered even further by the tax deductibility of mortgage interest in a time of high marginal tax rates; and the extension of college education - more a matter of increasing status than improving skills - to groups that previously would never have been able to afford it. This was the "Quiet Generation," quiet because times were good and families needed building.

These new, middle-class Americans, still segregated by income, sought to leave their familiar urban neighborhoods for the suburbs. Their reasons for doing so were many and conflicting. They sought to escape the rising tide of black migration to Northern cities that had picked up during the war and further increased with changes in Southern agricultural practices, such as the introduction of the mechanical cotton picker, that made the sharecropper's or tenant farmer's already precarious livelihood even more fragile. They also sought to escape the family pressure that was omnipresent in old ethnic neighborhoods of multiple family dwellings wedged closely together. Especially, they hoped to fulfill that quintessential American dream, sold endlessly in the popular press as well as by producer advertising, of owning one's own home. In their separate suburban enclaves, often still as separated by ethnicity, as well as race, as were their old neighborhoods, these individuals created a middle class that was both different from that of the classic bourgeois shopkeeper or professional of nineteenth-century Europe and America or from that of the salaried middle management ubiquitous in corporate life since the latter part of that century, and far larger in scope 
than had ever been seen before. They were the first wage-earner middle class.

Meanwhile, the combination of Marshall Plan aid and NATO-related expenditures in Europe and similar economic aid and Korean-War-related expenditures in Japan, plus low domestic defense expenditures in both areas and incredibly high savings rates in Japan meant first slow, then explosive growth in the mid-fifties. As a result of this growth, the American balance of trade, the measure of current exports as against imports, which had regularly shown a surplus, began to decline. Consequently, given the continuation of governmental expenditures abroad, largely military after economic aid was ended in the early fifties, the declining positive balance of trade allowed the development of a negative balance of payments, the measure of total currency and gold outflows as against inflows.

Initially, that negative balance of payments was good for a world economy that was short of payment reserves. It allowed foreign countries to build up reserves, particularly of dollars, the reserve currency of choice. However, by the late fifties, what was once a good thing and remained so because an increase in reserves was essential for financing the continuing growth in international trade, given that a sufficient increase in the gold supply was not forthcoming, also came to be seen as troublesome. The first call on the American gold reserve was as fractional backing for the dollar as a domestic currency. The balance of the reserve was, under the gold exchange standard, held to guarantee the American pledge to redeem in gold the dollar holdings of foreign governments at the $\$ 35$ per ounce ratio set by the Bretton Woods agreements. This guarantee of redemption was fine, so long as no foreign government sought to exercise the right to redeem its dollar holdings. Unfortunately, foreign governments did just that, and the gold reserve slowly was being depleted.

With outstanding dollar reserves exceeding the gold available to back them, the possibility that someone would be left without a chair when the music stopped began to worry foreign governments. These governments feared that the United States would devalue its currency, unilaterally increasing the price of gold and hence the amount of foreign dollar holdings required to be exchanged for a given amount of gold. At the same time, the U.S. government feared that devaluing the dollar would both spark domestic inflation and bring about an international economic crisis that could undermine the strength of the anti-Communist coalition that seemed essential for Western security. Thus began a period of intense official concern about the balance of trade, balance of payments, dollar outflow, current account, and other measures of a "problem" that most Americans couldn't understand, in part because the language used to describe the problem was so multifarious. 
The first concrete and separable manifestation of that problem came in the early sixties. With the gradual opening of capital markets worldwide, European companies discovered that they could take advantage of a regulated American banking market that, because of the New Deal reforms, kept capital costs low in the United States, significantly lower than they were in Europe. These companies would borrow dollars in New York and use them to pay for capital investments abroad. Such a sensible business strategy had the obvious effect of increasing the supply of dollars abroad, a private outflow of capital on top of the governmental outflow for military and aid purposes, and so of increasing the balance of payments deficit and concomitant worries about the American gold reserve. In I962, in an effort to reduce that outflow and the accompanying worries, the Kennedy administration introduced the interest equalization tax. This tax was designed to increase the effective interest rate on bonds denominated in dollars and sold in the United States by foreign borrowers to the interest rate that would have been paid on similar bonds had they been sold in foreign markets, and so to discourage the issuance of such bonds, by taxing American purchasers of the bonds.

The temporary success of this tax strategy is far less important to understanding the American economy in the immediate postwar period than two other things. First, the need to impose the tax serves to mark a significant change in that economy. For the first time in more than twenty years international economic activities were having a negative impact on management of the American economy. The interest equalization tax affirmed, though no one understood this at the time, that the United States was no longer an economic island. Domestic economic policies would thereafter have to be recognized as having international effects and foreign economic policies recognized as having domestic economic effects.

Second, although the imposition of the equalization tax largely ended the market for bonds denominated in dollars and sold in the United States by foreign borrowers, it did not dampen the demand of foreign corporations for dollar-denominated loans. Governments may have been worried about the American balance of payments, but borrowers were not. So, the market merely moved elsewhere - to the Eurodollar market, which is to say, really nowhere. That market, apparently born in the mid-fifties when the Russian government wanted a place to keep its dollar earnings where the American government could not confiscate them, lends dollars deposited in banks located in various countries in which the dollar is not the national currency. Somewhat unaccountably, such deposits are not subject to bank reserve requirements, which means that these lenders can offer lower interest rates than would be asked for loans in their various national currencies. Though such rates were not as low as American rates, the difference was still sufficient 
to be attractive to European borrowers, and so in time these deposits grew enormously. The growth of this market affirmed the dollar's central role in trade and investment worldwide, and, paradoxically, its role as an effective reserve currency, even as governments were worried about its "soundness." After all, the United States was still the largest economy in the world.

\section{Law and Economic Change: A Second Interrogation}

The most obvious indication that one is confronting an economy in full bloom, as it were, is that as one tries to tell its story there is almost nothing to talk about for there is almost nothing going on. The economic actors have settled into playing the economic roles that the economy seems to assume that they will play. Law is quite silent as well. Such is the case with the associationalist economy of the fifties.

After the adoption of the Taft-Hartley Act in 1947, there is but one significant piece of economic legislation in the succeeding fifteen years the Interstate Highway Act of 1957. And that piece of legislation is more of a reflection of the impatience of the enlarged middle class with the limits on their ability to use their big cars and leisure time, their two weeks of paid vacation, than a reflection of any troubles that would cause those harmed to run to law for its uncertain succor. All of this is not to say that the organs of law shut down during these years. Rather, the legislative product - the expansion of the rice support program to two more counties in Arkansas where the existence of such support made it newly plausible to grow rice or the creation of a public authority to extend an airport or maintain a port was so trivial as to beggar the mind.

The relative silence of law is, of course, misleading. Narrowly conceived as just the formal and effective norms originating from governmental entities, especially the law of property, contract and theft, of mine and thine, law is always there, the modest hum of a faithful dynamo. Looking at law more broadly conceived, as the many and variable actions undertaken by governmental actors, of discretionary action, as the traditional language of the law would have it, the matter is pretty much the same. Because in an enacted economy the formal and effective structures are pretty much in place, the work of the bureaucracy goes about its modest regulatory business constantly, but quietly. Yes, noise is always heard from narrowly interested parties and that noise bulks large in the business press, but when looked back on, tempests and teapots come readily to mind. This is the real significance of the interest equalization tax, buried as it was in an otherwise ordinary omnibus tax bill. Law was finally roused from its quiet work to attend to what in the longer run turned out to be a significant problem. The associationalist economy was in trouble. 


\section{THE SIXTIES AND SEVENTIES: A TROUBLED ECONOMY}

For about the next twenty years, an increasingly troubled economy, centered in the production of consumer and heavy industrial goods, alternately slid and lurched down hill. How troubled? After the invasion of the Volkswagen Beetle, it took a flotilla of inexpensive Japanese imports to begin to knock the automobile industry out of denying that its market had changed. "Voluntary" export restraints entered into by Japanese manufacturers, designed to give the industry time to get back to its fighting weight, seemed not to help. Then there was the continuous decline of a steel industry that, once deprived of the stimulus provided by the Vietnam War and plagued with excess capacity devoted to an aged production process, ceded market after market to substantially cheaper imports and domestic upstarts, even while receiving trade protection. Similar stories might be told in the case of textiles (again despite significant trade protection), machine tools, clothing, footwear, and, of course, the television set, that quintessential product of the fifties life and economy. Most of the areas in which significant declines did not occur were industries where comprehensive federal or state regulation was in place, such as aviation, banking, communications, power, and securities. The only real growth industries in this period, other than entertainment, were real estate, plus the associated construction enterprises, and higher education, plus the associated spinoffs from the production of technological research conducted in medicine, electronics, and other scienceand engineering-related fields.

How did this state of affairs come about? Initially, foreign manufactured products were attractive simply because they were cheaper. The associationalist model of a high-wage, high-price economy made it difficult for newly prosperous younger and lower-middle-class consumers, the expanded middle class that the fifties economy brought into being, to afford many things, especially small appliances and other electrical goods, or much of many things that were affordable only in small amounts, mainly soft goods. The discount stores that had begun to appear in the fifties - stores like E. J. Korvettes that sold American made hard goods at "discount" (i.e., less than the high "list" prices charged by the small Main Street retailers) - soon turned into specialty retailers, such as Pier I, or into moderate-income department stores, such as K-Mart, Ames, or Hills, that sold many foreignmade goods, first soft goods, later small appliances, eventually electronics. Now, these families could have more clothes in their closets and small, inexpensive appliances in their kitchens; eventually they could have cheaper electronics in their family rooms.

Foreign products, especially soft goods, small appliances, and consumer electronics, often were cheaper simply because of wage rate disparities. 
For other products such as steel and autos, lower wages combined with an unexpected advantage that derived from the wartime destruction of industrial capacity in Europe and Japan. Overseas, once capital could be assembled to revive these industries, capacity was built with the newest, most efficient technology and work processes - production methods in advance of those existing in the United States. The combination of better methods and lower wages was sufficient to offset the quite significant cost of ocean freight for heavy, often bulky goods. Transportation costs for soft goods, small appliances, and consumer electronics, when combined with loss or damage from trans-shipping to boats and from boats to trains or trucks, were a similarly significant expense. But, in time, transportation costs for these goods came down radically with the development of containerized shipping and of ships designed for containerization.

Eventually, foreign manufactured products were attractive because they were better. As foreign wages rose, first in Europe and then in Japan, producers there relied on technological advances that reduced costs or on mass production of new products - the Walkman stereo and the videocassette recorder are the best known - often actually invented in the United States. Faced with persistent consumer demand for low- priced or relatively inexpensive newly available products, American companies, used to oligopolistic competition, were not able, or at least not willing, to compete. Their response was to cede the low price market, as the steel industry had done, or to move production overseas. In either case, American companies eventually shrank domestic manufacturing capacity. Only later was "automation," the choice to substitute increasingly sophisticated machines (often manufactured abroad) for labor power, tried and then only sometimes successfully.

Explaining this pattern of manufacturer behavior is difficult. In some of the heavily unionized sectors such as steel and autos, management - fat, happy, and always inordinately concerned about its prerogatives; labor - a relatively immobile factor of production that can be expected to fight hard to preserve jobs; and especially poor labor-management relations, forged from the notion of quid pro quo, rather than the notion of joint problem solving, bear some share of the responsibility. In other unionized and in nonunionized sectors, family and management ties to declining enterprises, a sense of obligation toward local communities, possibly a sense of continuing obligation to workers derived from their status as veterans, and of course drift and default seem to have played a role. What is most significant, however, is that, in a surprisingly large number of cases, plant closure was avoided for as long as possible. Such was the strength of the associationalist model in the late sixties and seventies, long after it ceased its relevance to America's place in the world economy. 
While the dysfunctional post-fifties American economy slid comfortably downhill, five developments silently continued to transform the country. The first was the malling of suburbia. This process largely destroyed the existing suburban versions of Main Street and continued the retail evacuation of the urban business core that had begun with the accelerated growth of the suburbs in the fifties, a development that only hastened the residential evacuation of those same cities.

The second development accompanied the completion of the interstate highway system. Initially, the existence of these highways magnified the evacuation of urban areas by their white, newly middle-class population. Then, in the same way that the new highway system had opened large tracts of land for residential development, it opened similar tracts for the development of light industrial and expanding service employment, particularly in banking, insurance, and health care, all within easy reach of this new suburban housing. Thereafter, jobs followed housing and housing jobs in a reinforcing cycle that created new suburban communities. Unlike the upper-middle-class suburbs of the twenties and thirties, these new suburbs were surprisingly independent of the urban areas that had initially spawned them.

The third development was the continuation of the evacuation of rural America, especially the Midwestern breadbasket. Though federal subsidies kept agriculture profitable, as farms increased in scale to pay for increasingly expensive hybrid seeds, chemical fertilizers, and equipment, the farm population declined. During these years, it was a real achievement for a rural community simply to maintain its population, even with recruited industrial employment, usually from firms attempting to escape a unionized work force, unless luck placed a growth industry - higher education was the most obvious one - in the area.

The fourth development was the growth of the South and West. In the South, the out-migration of blacks displaced by the mechanization of agriculture was offset by an even larger in-migration of Northerners escaping declining industries and chasing manufacturing jobs that were fleeing union labor contracts. In the West, aerospace and other military-related jobs were the draw. In both areas, the climate was made increasingly habitable by the perfection of air conditioning. And, as cities grew, construction and service jobs grew in tandem.

The fifth development was a significant change in the structure of the American industrial firm. Traditionally, industrial corporations, vertically integrated to a significant extent, made one major product and a few closely related ones. Such firms grew from the investment of retained earnings, either internally or by merger with other firms in the same industry. But in the sixties this type of growth by merger was stymied by the 
Celler-Kefauver amendments to the antitrust acts. Apparently responding to this limit on growth, many American corporations began to use their retained earnings, in the form of new issues of common stock, to purchase strikingly diverse businesses, building what were called "conglomerates," the most famous being Harold Geneen's ITT and James Ling's LTV. This innovation unfortunately coincided with a steep decline in average annual increases in American productivity, from about 3 percent in the late fifties to nearly zero percent by the end of the seventies, and in corporate spending for research and development. For the time being, it seemed as if the traditional industrial corporation, already under siege by foreign competitors, would be succeeded by another form of industrial organization.

The slow slide of the American economy downhill that accompanied these social and economic changes was occasionally interrupted by less gentle lurches toward the bottom. The first such lurch followed from Lyndon Johnson's decision simultaneously to fight a land war in Asia, build a Great Society, and maintain the free importation of goods lest the American standard of living decline, but not to raise income taxes - a policy that Richard Nixon continued, though by diverting Great Society expenditures, and more than a few others, to the cause of Mars. Thus began a string of federal governmental deficits at a time when the economy was probably already operating at full capacity.

Unfortunately, during these years the Federal Reserve had adopted a policy of seeking regular growth in the money supply, further augmenting that supply during each recession under the Keynesian theory, by then generally accepted, that such action would lower interest rates and so expand employment. The result was the beginning of the Great Inflation, lasting close to a generation. By the time this event was over, it had reduced the value of the dollar by about two-thirds and the real value of wages by 20 percent. The newly broadened middle class was being seriously squeezed as interest rates increased significantly, especially on home mortgages; as the cost of common services, such as hair cuts and dry cleaning, not to mention more complex services such a medical care, began to accelerate; and as prices in the grocery and drug stores moved from a trot to a gallop.

The combination of inflation and a system of fixed exchange rates occasioned the second lurch downhill. Domestic inflation meant that, from the perspective of foreign buyers, American exports seemed more expensive; from the perception of American buyers, foreign imports seemed cheap. This disparity of perception led to a sharp deterioration in the American balance of trade as foreign buyers cut back on the purchase of American goods and American buyers clamored for more imported goods. Simultaneously, the further restrictions on the outflow of funds that were imposed soon after the interest equalization tax not only failed to solve the American 
balance of payments problems, but those problems were augmented by the increased overseas military spending occasioned by the Vietnam War. This augmentation compounded the effects of the deterioration in the balance of trade; foreign governments began quickly to convert their dollars into gold. In I97 I, fearing that continuation of the outflow of gold threatened the "bankruptcy" of the country or, more properly, of the policy of guaranteeing the convertibility of dollars into gold at the fixed rate established by the Bretton Woods agreements, Richard Nixon, who had more than exacerbated the problem by intensifying the war in Southeast Asia, "temporarily" refused to honor the nation's commitment to exchange dollars for gold. Two years later, when circumstances had not improved, he abandoned the gold exchange standard entirely.

The demise of the gold exchange standard and its replacement with a system of "floating" exchange rates involving the major international currencies - rates determined in the market for foreign exchange and not by the willingness of governments to exchange currency at stated rates was not the disaster for the world economy that many had feared it would be. Indeed, like the interest equalization tax, the adoption of a floating exchange rate may have been more a symbol of the continued decline of the American island economy that had made possible the realization of the associationalist ideal in the fifties than of much practical significance, given that the dollar continued to be freely accepted as a medium of foreign trade and indeed, as a reserve currency. But everyone expected that the short-term consequence for the economy would be a further increase in inflation.

Recognizing this expectation, when Nixon closed the gold window in I97 I, he simultaneously took the unprecedented step of instituting wage and price controls in an allegedly peacetime economy. Such controls were anything but unwelcome to the American people, unused as they were to annual inflation rates of 6 or more percent. In addition to placing stress on family budgets, such inflation even decreased disposable inflated income, as wage increases were also eaten into by increases in marginal income tax rates as a result of moving to higher tax brackets. Controls, progressively weakened, were about as effective as could be expected, more so possibly because they were not in force long enough to spawn a fully developed black market.

Inflation, however, continued unabated. Indeed, next the economy experienced two more lurches toward the bottom, each accompanied by a significant increase in inflation. In 1973 came the Arab oil embargo that followed the Yom Kippur War, which when lifted was accompanied by the decision of the Organization of Petroleum Exporting Countries (OPEC) to quadruple the price of oil. The unemployment rate hit 8.5 percent. Then, 
in 1978 came a second shock, that from the loss of access to Iranian oil in the aftermath of the Iranian Revolution and from the further OPEC price rise that followed. Because the United States had become highly dependent on importing countless tankers of now very expensive oil, its balance of trade, already significantly negative, declined precipitously, and soon the world was awash with dollars.

Curiously, during these years, the most extraordinary - but usually unremarked - aspect of the American economy was the general inability of economists and policymakers to explain persuasively, much less to act effectively to alter, the cumulative slide in that economy. How it came to be that inflation did not bring economic growth, its traditional accompaniment, but instead allowed the continuance of a relatively stagnant economy - the dreaded "stagflation" - was a mystery. And not a pleasant one. The largest economy in the world was in real trouble.

\section{Law and Economic Change: A Third Interrogation}

Watching an economy come apart is not likely to be a pretty sight, and the disintegration of the associationalist economy during the sixties and seventies was no exception to this generalization. The bewildered, human pain that followed as solid expectations of future life were completely unraveled - labor, management, adolescents, and old people alike in their pain, though not in their loss - is perhaps the most characteristic aspect of these years. Gasoline wasn't supposed to cost a dollar a gallon; wages weren't supposed to lag behind inflation; imports weren't supposed to threaten established supports of community life. And this disorientation included public life; America wasn't supposed to be a pitiful, helpless giant suffering from economic malaise, as Jimmy Carter learned to his dismay.

That the experts could make no sense of these events is an understatement. Arthur Laffer could take a cocktail napkin, draw a curve on it that linked declining income tax rates with increasing tax collections, and it became a theory, somehow just as strong a theory as Milton Friedman's theory about changes in the growth of monetary aggregates and inflation, based as his was on years of research in monetary history. Ideas for taming inflation as sensible, but unprecedented, as Richard Nixon's embrace of peacetime price regulation and as silly as Gerald Ford's distribution of WIN (Whip Inflation Now) buttons were both worth a try because no one could understand what was going on anyway. Maybe a conglomeration of companies was a good idea if a group could be assembled so that the profits of its component parts experienced different temporal cycles, some always up when the others were down, so that the company as a whole always would be profitable. But 
then, maybe it was really dumb to assume that management by financial statement was better than management from the factory floor. Either was obviously arguable.

Law understood no more than the humans who used it. People felt pain, felt the times to be out of control, and so went to law in search of whatever nostrums seemed plausible at a given time and place. Trade protection made as much sense as did abandoning the gold standard as did reinvigorating antitrust enforcement as did price control as did price decontrol as did the strategic petroleum reserve as did airline price deregulation. As was the case during the Depression, people were hurting, and so law responded in such ways as the practical politics of the legislative process at that time and place allowed.

But to mention airline deregulation, a piece of the puzzle that only fit into $a$, not the pattern years later, is to bring to the fore something very important with respect to law and economic change. Although sensible people might have understood that the associationalist economy was coming apart and was not likely to be put together again, no one knew what kind of economy was in our future or even when a new economy might come together. No set of structures was put into place, intentionally or accidentally, that forged the next economy, except in the sense that lots of structures were tried that might or might not prove important depending on what happened next in economic life. The two nostrums that proved to be harbingers of things to come, the laughable Laffer curve and the deregulation of airline fares, do not bulk particularly large in any sensible story of these years. Indeed, it is hard to see exactly what the notion that raising the effective return on invested capital would aid the economy had to do with the notion that reducing price rigidity would have the same effect, except on the goofy theory, belied by the good years that were the fifties, that governmental regulation was somehow always and everywhere an economic mistake.

\section{THE EIGHTIES AND NINETIES: BUILDING AN IMPATIENT ECONOMY}

One day in October I979, Paul Volcker, newly chair of the Federal Reserve, decided that he had had it with inflation. He convinced the Fed to scrap the conventional wisdom; it would no longer increase the monetary supply in order to stimulate the economy and would let interest rates rise and fall as they pleased. Soon, interest rates hit sky-high levels, and in I98I the country dropped into a deep recession that lasted for two years. The unemployment rate reached io percent. About the same time, Ronald Reagan both increased defense spending and cut taxes, producing enormous deficits in the federal budget. These actions helped pull the economy out 
of the recession that Volcker had created, once again proving that Keynes was most useful to those who did not believe in his prescriptions.

When the recession was over, the Great Inflation was over as well. Apparently, the precipitous rise in nominal interest rates in the early eighties interacted with a rise in real rates of return to boost the attractiveness of investment in capital assets and bring a decline in the actual rate of inflation. Such assets, especially those implementing newly developed technologies often related to computerization in both manufacturing and service industries, changed the structure of production. They tended either to increase the entry-level skills needed to operate production processes and so widened the gap between those skills, and the wages appropriate to them, and the remaining grunt jobs, or, as was particularly the case in the service sector, decreased the skill level and often the absolute number of entry-level jobs. In either case, the associationalist model of the economy was undercut.

A similar undercutting was felt in diverse segments of the economy. Among the ideas offered in the seventies to explain the dismal condition of the economy was the proposition that it was rooted in excessive regulation. Although the most heavily regulated sectors of the economy communications, energy, and transportation - were few in number and generally entailed only modest direct costs for industrial producers, and the more lightly regulated sectors - banking and securities - arguably had been a crucial economic engine during the fifties by keeping capital costs low, numerous legislative programs of deregulation were adopted during these years. The effect of these programs was, however, mostly felt in the eighties.

Examples are numerous. In air travel, first came the disappearance of the single- price airfare, always and at any time the same, and the proliferation of cheap restricted fares, an event that helped airline traffic grow into a mass-market phenomenon in ways that it never had been before. Then came bankruptcies, consolidation, and the development of a hub-and-spoke route system that worked both to lower costs and to make new entry difficult, but allowed smaller niche players to emerge. A similar pattern developed in both truck and rail transport: lower costs, fewer, larger firms as a result of bankruptcy and merger, and small specialists. In all three areas a large, government-stabilized cartel was succeeded by a smaller oligopoly.

In communication and finance the sequence was different and the time frame longer, but the end point was much the same. First came lower prices the decline in long-distance rates and the abolition of fixed commissions on stock trades - and then a great proliferation in new services: call waiting and cell phones, interest-bearing checking accounts, and automatic teller machines. Eventually came consolidation into seeming oligopolies, though in these cases less through bankruptcy and more through merger. 
The effect on the economy from deregulation was not quite what the theory predicted. Prices did decline for most consumers, except for the road warriors of corporate sales departments who shifted from long boring rides in large comfortable cars ending at indifferent motel rooms to shorter cramped flights, boring waits in airports, and short drives in cramped rental cars ending at indifferent motel rooms. More significantly, however, in each deregulated industry the product or service seemed to change over time.

The simplest example is rail and truck transport where the transformation of industry structure combined with the potential of computerization to produce "just in time" manufacturing and retailing, a concept that significantly reduced inventory costs and eliminated dozens of local distributors. Trucks, rail cars, and ocean freight containers, always on the move, in effect became the inventory function, serving as rolling warehouses. Similarly, in communication first the fax machine, then the dial-up modem, and finally cable and wireless technology, again combined with the potential of computerization, transformed the humble phone call into something else - a document delivery service, an information-retrieval mechanism, a "realtime" financial transactions network. These changes transformed the phone into bandwidth to be used for purposes essentially unrelated to inviting neighbors over for dinner and a friendly game of cards. Likewise in banking and securities, the proliferation of products that are neither deposit taking nor lending nor the purchase and sale of debt or equity interests in business entities - bank cards, money market mutual funds, securitization, currency hedging, interest rate swaps - have created what can be seen as a new industry, rather grandiosely called financial services.

A significant portion of the economic growth in the late eighties and nineties came in these areas, though not without costs, often enormous, for the political process failed to realize that regulation creates patterns of investment, and so of personal commitment, that are upset when regulation is removed. In the securities industry predictable and promising careers ended and famous firms were swallowed whole, as competition created the need for new products and new skills. In railroads, the casualties were other industries that, and people who, had located in particular places and there depended on the existence of a particular mode of transportation that was no longer economical to maintain and so disappeared.

In bank regulation the matter was more complicated and ultimately expensive, but again had its roots in the seventies. The Great Inflation brought an enormous increase in unregulated interest rates. Soon there were complaints across the land that savings deposits were "eroding" because they were earning a regulated low return, a rate far below the rate of inflation. To make matters worse, the development of the money market mutual fund, a device that invested cash in short-term Treasury obligations and similar 
debt instruments of the most credit-worthy commercial borrowers commercial paper - offered savers a heftier return than could savings accounts, because the rates on these investments were not regulated. In pursuit of such returns, savings poured out of deposit institutions. Savings and loans found that they lacked money for making new mortgages. Banks found that demand for corporate loans had declined as corporate treasurers issued the commercial paper that the money market funds craved, rather than visiting their local banker.

The initial governmental response to this problem was to allow commercial banks to offer interest on checking accounts and the savings and loan industry to offer higher rates on its deposits. The banks, left with a riskier portfolio of loans made to borrowers whose credit was not good enough for the commercial paper market, moved heavily into fee-generating business to pay for the now more expensive deposits. The savings and loans had a more embedded problem; the interest rates they were now paying for deposits were substantially higher than the interest rates on the portfolio of thirty-year mortgages they had made over time and still held. Thus, although these institutions had funds to loan, they were losing money with each transaction. Two changes followed.

The first was a great success, the invention of the collateralized mortgage obligation (CMO). Financial institutions would sell their mortgages to the New Deal's federal mortgage organizations - the Federal National Mortgage Association (Fannie Mae), the Federal Home Loan Mortgage Corporation (Freddie Mac), and the Government National Mortgage Association (Ginnie $\mathrm{Mae})$. These organizations had long sold their own bonds to provide funds that could be lent to the providers of home mortgages. Now they began to issue similar securities, CMOs, with their own, extremely valuable guarantee and moreover collateralized by the newly purchased mortgages. This set of transactions allowed financial institutions to shift the risk of owning mortgages with fixed long-term rates to institutions with less sensitivity to interest-rate shifts, such as pension plans and insurance companies.

The other was anything but a success. In the name of maintaining fairness between different types of financial institutions, savings and loans were permitted to engage in lending other than home mortgages with the hope that they would earn the greater returns that those forms of lending provided. This decision was followed by the savings and loan crisis of the late eighties, as savings and loans around the country folded because of bad, occasionally even corrupt, investments or continuing "negative spreads" between deposit interest rates and mortgage portfolio returns, or both. The Treasury paid out billions on the claims presented by depositors who lost their savings in the process, an obligation that derived from the provision of deposit insurance, one of the little programs of the New Deal that had 
successfully enticed deposits back into a banking system that had imploded in the twenties and thirties.

Deregulation was, however, only a part of what was going on in the economy in the eighties and nineties. Much of the rest was the continued destruction of the economic model that had made the fifties economy such a spectacular thing, probably by accident, by being the right model for that particularly unforeseeable time. Increasingly, the associationalist model of high prices, high wages, and lifetime employment, at least for white-collar workers, came undone in a range of industries, whether trade protected or not. Copper, tires, textiles, clothing, shoes, televisions, stereos, dishes, glassware, cookware, watches, pens, and even telephones slowly became mostly imported products; autos, somewhat less. Manufacturers continued the process of first conceding the low-end products, then the oldest manufacturing facilities, and finally whole markets.

In some areas technological innovation or the development of new processes entirely - steel mini-mills using scrap for feedstock is a good example - kept parts of old industries alive. But more than occasionally, these were markets where manufacturing costs were not yet matched by foreign producers. In still other markets, a slimmed-down industry survived in niches - autos that are particularly designed for the odd tastes of the American consumer or specialty steels. What was left behind was a landscape surprisingly denuded of former industrial icons, except for a few long-term survivors. IBM, as well as Boeing and the rest of the aerospace industry, are the most obvious; General Motors and Ford, the most recurrently troubled. Even the conglomerate alternative to the fifties industrial behemoths passed from the scene, a victim of the eighties junk bond craze that facilitated busting up such entities for fun and profit.

As one examines this record of the decline of heavy industry, it becomes apparent that the broad increase in the standard of living that took place in the fifties and early sixties has been America's own version of the winner's curse. Although Americans have always searched for new markets and so have been alive to the world of international trade, free trade, and thus the idea of comparative national advantage, has been a more central part of the national consciousness since World War II. Free trade, really freer trade, was to be a way to avoid the recurrence of the Depression, to unite nations by means of growing mutual dependency, and to provide an object lesson for the Third World of the benefits of "open" economies, in contrast to the "closed" Communist economies in Eastern Europe and Asia. Foreign policy thus supported freer trade, though at times domestic considerations made freer trade look more like trade managed for strategic national advantage.

Freer trade interacted with the American standard of living in a crucial way. As the United States became less of an island, less capable of standing 
separately, maintaining the standard of living that was built in a high-wage, high-price economy became more difficult. In response to that difficulty, Americans, fighting to remain a part of the enlarged middle class, did many things. They drastically curbed saving. They supported tax reduction, borrowing from an uncertain future. They chose to try to stretch the dollar by working harder; the growth of the two wage-earner household during the seventies and eighties surely cushioned economic decline for families who found that local industrial jobs had disappeared. And they found it easy to continue to accept, indeed to increase their acceptance of, lower cost imports from an international arena with which they were familiar and in which they were comfortable, if not wholly dominant. That arena became the source for the goods that were necessary for membership in the lower middle class and above.

Of course, because of America's economic dependence on imported oil environmental concerns, again a part of a middle-class standard of living, have kept coal and nuclear power from being winners - and because of American's addiction to computers and consumer electronics, there was really no other plausible choice than freer trade. Letting the dollar become a reserve currency, indeed even exulting in its becoming such, was, like the middle-class standard of living, a mixed blessing. It made trade easy, but it made investment easy as well. The interest equalization tax had a hidden lesson in it. Capital does seek its highest returns consistent with its tolerance for risk.

Once the value of major currencies was no longer tied to a stock of gold, numerous investment opportunities, denominated in various currencies, became real alternatives. Looked at critically, returns on investments denominated in dollars simply did not stand up to those available elsewhere. And so, those American firms that could move their funds around the world found that more promising investments in plant and equipment were to be had elsewhere. Often these investments were made simply in pursuit of lower labor costs. At other times, investments were in new production processes, especially those substituting lighter weight components for heavier, since the modest increase in the cost of production was less than the decrease in the cost of ocean freight and so the resulting product was still salable in the United States. Though investment in new plant and equipment was concentrated elsewhere, buying was still an available alternative for middle-class Americans addicted to their standard of living; increasingly, manufacturing was not.

There was, as often is the case, a counter-current. Ours was still the largest economy in the world, though the expanding European Union was trying to overtake us. Our addiction to a fifties standard of living maintained with imported goods meant that foreign producers rapidly acquired 
great piles of dollars, for most the reserve currency of choice. Those earnings had to go somewhere. Mattresses were implausible and conversion to foreign currencies would only result in a decrease in the value of the earnings. So, many producers of imported goods used their dollars to make portfolio investments in New York, the largest and deepest securities market in the world; to purchase tangible American assets, such as real estate, still viable manufacturing companies, or almost any service business; or to duplicate their existing, overseas plant and equipment in the States, thus saving the transportation costs otherwise inherent in serving our market and simultaneously making their products more attractive to American customers. Oddly, what seemed to many observers to be a dangerous tendency to live well beyond our means proved to be not even a half-bad experience for many Americans.

As the remnants of the fifties economy were being destroyed, a successor economy was growing, developed out of America's real economic strength - higher education. Computers and their software, pharmaceuticals, health care products, electronic technology spinoffs from defense industries, advanced engineering processes - all were high-growth, high-return industries right here in America; all were significant sources of exports as well. It seemed as if Americans were going to do the world's research and development. Production was another matter. All major (and a surprising percentage of minor) American corporations purveying consumer or industrial goods had built or acquired many international facilities capable of producing goods for local markets and for export to the United States. Production would increasingly be done elsewhere.

Another source of growth was in the continuing expansion of service industries: banking, insurance, real estate, health care, "hospitality," travel, and government. This was particularly true in the South and West, areas that had already increased their light-manufacturing base and so could support a similarly increased population. In Florida and in the Southwest, where the natives had expanded water supplies through transport by canal, growing numbers of retirees fueled still larger increases in the size of the service economy. In a real sense, service jobs too were a product of the American system of education, though not necessarily one to be proud of, filled as they were by a small number of college and professional degree holders and a large number of others who at best held associates degrees and were paid accordingly.

These examples of growth were obvious in that other notable product of the American educational system - the financial services industry. The proliferation of new and modestly useful financial products coming out of Wall Street's version of Hollywood's dream factories that took advantage of the breadth and depth of the American capital markets and tapped into 
international markets as well made many men (but few women) rich. In the process, the financial engineering that Wall Street delivered to the various "institutions" that increasingly came to dominate American financial markets - insurance companies, mutual funds, pension funds, the private foundations of the wealthy, university endowments and, let us not forget, hedge funds - transformed the financial landscape. Where once a solid dividend record was all that counted when measuring a stock's attractiveness, now institutions - many so large that they would find it very hard to sell their holdings in any given stock and others limited in their ability to do so by their choice to pursue indexing as an investment strategy - gave attractiveness an entirely new dimension, a dimension derived from the new high-growth, high-return industries. Total return, the sum of dividends received and stock appreciation, was now the measure of investment success, that and steady earnings growth. All one heard was the demand for "increasing shareholder value," a euphemism for raising a company's stock price.

So, at the end of the nineties the United States seemed to be left with an economy that consisted of the products of the American system of higher education; those things that were too heavy and too inexpensive to be effectively made and shipped from overseas; services that had to be delivered locally including construction; entertainment, always a viable industry for any cultural hegemon; autos, an industry kept alive by the growth of foreign manufacturers who, afraid of trade protection legislation, chose to use profits earned here to create plants producing for a market once served from abroad; and the sale of the myriad products that made up a middle-class lifestyle. While some argued that the industries reborn by deregulation had to be added to this list, it seemed more likely that, just as had proven to be the case with truck and rail transportation, unless the deregulated industries were tied to the products of the American system of higher education, their growth would prove to have represented one-time opportunities as, over time, the American preference for oligopolistic competition - a modest possibility of price control derived from branding and economies of scale, coupled with an endless fear of a competitor's "breakout" innovation asserted itself.

To know something is to be able to name it. If the fifties instantiated an associationalist economy, what name properly describes the American economy at the end of the nineties? The decade did not see a return to the laissez-faire capitalism thought to have gripped the United States in the I 890 . For all the complaints about the costs of regulation, environmental, food and drug, labor relations, occupational safety, pension, product safety, securities, and wage and hour protections did not wholly disappear. Social 
Security and Medicare, as well as unemployment, bank deposit, pension, and brokerage failure insurance survived as well. The economy did not emulate the Gilded Age financiers and break into an orgy of unrestrained, to-the-death competition. Nor is it likely that it will. Oligopoly is too much a part of the American and world experience now.

To understand the economy that emerged from the nineties, it is important to notice how, during the decade, financial markets became incredibly disciplining. Companies had to deliver ever higher total returns on capital based on steady, predictable earnings growth or face pressure to cut losses quickly. This was an unforgiving economy, an economy where people with the labor market skills of the hour were pampered as never before, but only for as long as their star shone brightest. No longer associationalist, the American economy had become an impatient economy.

The associationalist economy promised that economic growth would increase the availability of leisure; in response, some commentators even began to worry that so much leisure time would become a social problem. In the early twenty-first century all that is past; now there is no leisure time until retirement. The communications revolution means that the global stock market, which operates around the clock, can be checked at any time in the day or night while on safari in Africa. First, courier largely replaced real mail; in turn courier was replaced by fax; currently the on-time standards are email and text messaging, available essentially anywhere, anytime by mobile phone. Coast-to-coast and intercontinental flights are staples of commerce, where once the pace of train and ocean travel - both with real sleep caught on the way - was a break from the daily routine. Financial markets are driven, not by earnings trends, but by quarterly earnings, or even expectations about quarterly earnings; by expectations about the next Fed Open Market Committee meeting and not by the results of the meeting itself. The best production process is a "just in time" production process. Yes, in the early twenty-first century the American economy is an impatient economy.

\section{EXAMINING A LOOSELY WOVEN FABRIC: SEEKING LAW IN ECONOMIC CHANGE}

Whether one focuses on the details of economic life - dominant industries, modes of transportation, consumer products - or on larger scale phenomena - the expansion of the consumerist middle class, the shift in sectional economies, the decline of the American island economy - or on the highest level of generality - an economy as a whole, a persistent market structure that fuses an understanding of economic life with patterns of behavior within economic, political, and social institutions, an associationalist or impatient 
economy - the short twentieth century has been a time of significant economic change. As such it is plausible to examine the role of law in economic change, first at the highest level, then at lower levels, by focusing on these years. $^{2}$

\section{Forms of Law and Change from One Economy to Another}

I hope that by now I have provided sufficient evidence for my initial assertion that the institution that is law (the many and variable actions undertaken by lawyers and other governmental officials, the formal and effective norms originating from the practices of these individuals, and the systematic presuppositions shared among them) did very little to bring about change from one economy to another. Though responding to distress when it wished, law mostly stood by and watched. Many changes happened; few might be traced from the actions, or back toward the reactions, of law. Capitalism as a form of economic organization seemingly went its merry way, complaining from time to time about law's particular intrusions, but generally too busy earning profits while profits could be earned, all the while coping with changes in markets, to be much influenced by law.

My assertion, contrary to so much of the received wisdom of law professors and legal historians alike, is not offered so much out of perversity, but in an attempt to get us beyond the legalism, the focus on the three forms of law enumerated above, that has infected the topic of law and economy for at least a century. That law in all three forms is important in the daily lives of humans is a proposition beyond question. That at times law attempts to have such an impact on lives is also true beyond peradventure. That it often fails of its intention is also reasonably clear. But great change, be it social, political, or economic, is not a matter for calculus - sum the impact of law on a large number of lives over the relevant range of years. Such change is not even a more irregular sum, but a qualitative experience that in retrospect is disjunctive, not additive, of this being a different time from some other, remembered or imaginatively recreated, time.

${ }^{2}$ Before doing so, it is important to note the futility of the task I undertake. Life is not lived in conventional academic boxes, even less the complex of lives that is a society at any time or times, place or places. Multivariate analysis makes sense only to the extent that all other things can be held constant, but they never manage to stay that way. More simplistic methods, such as mine, do not do the job of analysis any better, only differently. And so, as I attempt to separate "law" and "economy" in order to assess their respective roles in economic change, to separate the dancer from the music that together are the dance, I ask the reader to be tolerant of the intrusion of metaphor. It is, after all, a traditional way of capturing disparate elements into a readily, if only implicitly, understood whole. 
To understand the way in which law mostly stands aside as economic change occurs, not for lack of trying, but because it is the creation of humans, cursed with memory and deficient in foresight, let us look sequentially at the role of the three forms of law as set forth in my story. Looking first at the systematic presuppositions of the law, it is clear that, as asserted many pages ago, the law of property, contract, and theft, of mine and thine, so structures capitalism that it is both impossible to notice and impossible to miss. The precise effect of this distinctive underpinning to economic life is, however, difficult to gauge when examining economic change.

All change takes place within a systematic structure of law and is modestly pushed in particular directions by the alternatives that law, thus understood, makes possible. It is unquestionably true that, in the United States in the short twentieth century, the systematic structure of law made it difficult to conceive of a social democratic or communitarian alternative to any one of a range of capitalisms, much less a state socialist alternative. However, to identify this aspect of law as central to an understanding of its role in economic change is to reduce the question of change to a tautological one that assumes that the change from, for instance, capitalism to socialism is the only important economic change possible. For humans the lived experience of less momentous changes may seem just as significant; in any case, it is a dubious practice to try to understand an institution by looking at its participation in, or response to, the most extreme change imaginable. Less extreme changes are difficult enough to understand all by themselves.

Although it is difficult to know what an agnostic scholar might conclude about the role of law in large-scale economic change under hypothetical capitalist alternatives or alternatives to capitalism, I rather doubt that he or she would conclude that law played a significant role in such change. The systematic structure of law is largely isomorphic with the particular political economy - capitalism, socialism, or whatever - in this or any other of the various countries of the North Atlantic world. To identify specific instances of law's action or reaction surely is to pull individual threads out of a loosely woven fabric held together in so many other ways. For this reason I believe it is best to treat the patient, silent work of law seen as systematic structure as it appears to most economic actors, as invisible.

Looking next at the second form of law - formal and effective norms one can, of course, identify individual patches of law adopted for numerous reasons that turn out, often surprisingly, to be crucial supports for economic change, such as from an associationalist to an impatient economy. The expansion of the middle class was founded on the New Deal institutions that defined labor, housing, and finance in these years. The GI Bill and Cold War military expenditures did their part as well, as did the great growth of 
state university systems in the sixties. The shift in sectional economies was similarly founded on New Deal labor, agricultural, and industrial policies and on the concentration of new federal military and allied manufacturing resources in the South and West during World War II. The rise of the international economy of the last quarter of this century was founded on the multilateral financial and trade institutions established as part of the American strategy for an integrated postwar world, as well as on Marshall Plan aid.

However, no institution of law acted with even the vague intention of expanding the middle class as part of the development of a consumer society. Similarly, to the limited extent that wartime expenditures were designed to counteract the colonial nature of the Southern or Western economy, no one simultaneously wished to hasten the decline of heavy manufacturing in the Northeast, much less to shift the country as a whole toward a service economy. And, though the postwar financial and trade institutions and Marshall Plan aid were designed to foster international trade, the major point of that effort was to limit the possibility of renewed conflict in Europe, not to transform the international economy as a whole and American participation in it in particular. Thus, it is not wholly clear what to make of these more specific underpinnings for change beyond seeing them as examples of the law of unintended consequences. Probably they were reasonably essential to the particular large-scale changes identified and yet, there will always remain the nagging doubt as to whether the absence of one or more of these bits of law would have made much of a difference in the shape of such changes, any more than would a change in one or more threads alter a loosely woven fabric.

Looking finally at the third form of law - official action, the many and variable actions undertaken by lawyers and governmental actors - at least initially, this form seems more salient in the change from an associationalist to an impatient economy. Much of governmental effort directed toward managing economic life, both domestically and internationally, takes the form of, in the traditional language of the law, discretionary action. Lawyers worked endlessly to steer discretionary action and, when unable to do so, to avoid its objectives. This is the world of fiscal and monetary policy and international economic institutions, the world where economic historians argue about whether the Smoot-Hawley tariff really caused the Depression or whether Paul Volcker's actions to break the Great Inflation were effective in doing just that.

Clearly, Lord Keynes was right that such actions are of some causal significance. The question is how much and in what direction. The Kennedy tax cuts and Johnson's guns and butter (and no new taxes) policy clearly made a difference. But, it is not clear that they did more than provide very 
welcome life support for an economy built on an associationalism that was already facing problems with which it would be unable to cope. Similarly, twenty years of determined anti-inflationary policy, husbanded by both Paul Volcker and Alan Greenspan, made it easy for the United States to build its position as the broadest, deepest source of capital worldwide and, as the possessor of a reasonably solid currency available in large amounts, the effective central bank for the world. Still, it is not obvious that this tenacious policy preference did anything toward building a vital international economy other than speed up that process a smidgen by modestly lowering the cost of funds for the actors who were creating that economy, adding an occasional thread to, or adjusting an existing one in, the loosely woven fabric.

Gathered together, what all three forms of law - systemic presuppositions, formal and effective norms, and official action - seem to have done in the change from an associationalist to an impatient economy is to augment the prevailing winds, but modestly. Thus, the expansion of the middle class was aided by expenditures for schools and colleges, the development of urban road networks, permissive zoning for subdivisions and shopping areas, and the indexation of Social Security benefits. The shift in sectional economies was aided by the development of the interstate highway system, funding of the infrastructure necessary for expanded airline travel, toleration of sectional wage differentials, and the expansion of electrical capacity to support air conditioning in Sunbelt climates. And the rise of the international economy was aided by export incentives, policies favoring limited taxation of foreign income, support for the waterfront infrastructure necessary for containerized shipping, the relentless pursuit of tariff reduction, and support for the push by domestic banking and securities industries into foreign markets and for the creation of friendly domestic markets for foreign borrowers and investors. The contribution of the International Monetary Fund in attempting to stabilize currencies should not be underestimated either.

Now, none of these were trivial actions, and logically all could be inverted into a refusal to respond to claims for aid from those harmed by each of these actions. But all were at the time seen as "no big deal." Indeed, several of these actions taken by law do not even rate mention in any brief history of the American economy for these years. All might have been recognized as posing difficult problems at the time they were undertaken, but were not. Instead, they were seen as presenting no significant issues beyond the narrowly partisan ones. Their taken-for-grantedness is the key to understanding law's actions in these cases. What is taken for granted, what is merely a matter of course, is that which seems most natural, least controversial, in the eyes of the recognized participants in the "pointless bickering" about law and 
economy that always swirls throughout any governmental apparatus. And so, I believe it sensible to see such actions as no more than reinforcing large-scale change.

Why then is it that the best that law in its three forms can do in the face of the Schumpeterian "creative destruction" of capitalism is to augment the prevailing winds? Let me recapitulate. First, it is reasonably apparent that both economic and legal actors, to the extent that they may be more than formally distinguished, have at best a highly imperfect understanding of either economy or law at a given time and place. Second, this highly imperfect understanding is not the singular result of ideological blinkering, though, of course, all actors are both aided and limited in their vision as a result of shared or separate ideologies. Rather, both systems economic and legal - are significantly more complicated than most actors are capable of understanding. At the same time, both systems are far more subject to perturbations that these same actors believe are external to the systems than most of them can conceive. Third, economy and law are also significantly more integrated than these actors realize, particularly with respect to the legal infrastructure, both doctrinal and institutional, that silently undergirds and channels economic activity and with respect to the durable patterns of economic life that are instantiated by the humans who are economic actors in all senses of that phrase - consumers, workers, manufacturers, retailers, financiers, and the like. Thus, the failure of law to direct or to respond to large-scale economic change is not a failure to act on the dictates of intellect or even a failure of will, as Willard Hurst may seem to argue, but a reflection of the limited ability of humans fully to understand these two complex systems, a reflection not of policy failure, but of human fallibility, as it were.

\section{Three Attitudes Apparent in Law's Response to Smaller Scale Economic Change}

That law can do little but add to the steady winds of large-scale economic change does not mean that it cannot and so does not act, occasionally significantly, at the level of smaller, more narrowly focused change. Here, where actors can see more clearly, where the impact on the lives of Americans is more obvious, law should be able to pay attention to the consequences that economic change brings. And consequences there are. Any significant change in an economy - expansion or contraction, domestic or international, technological innovation or climatic alteration - will benefit or harm identifiable, limited segments of that economy - producers, financial or commercial intermediaries, transporters, sellers, workers, consumers - in a systematic way. Those who are harmed by such change routinely respond by seeking support to maintain their present, or regain their previous, 
economic position from whatever piece of the modern state that seems to them likely to offer such assistance - administrative, executive, judicial, or legislative. Sometimes the support sought will be forthcoming, though not necessarily in the form requested, and at other times such support will not be forthcoming. Oddly, even when such support is forthcoming, the support provided will only sometimes have the anticipated effects, and when the support is denied, the absence of support will only sometimes bring forth the anticipated consequences. Such is the recurrent, less than wholly helpful, pattern experienced by those who would go to law.

Despite the essential indeterminacy of law's reaction to smaller scale economic change, a few underlying attitudes can be teased out. I can identify three of them - law's general attitude toward change, its attitude toward technological as opposed to cost-driven change, and its attitude toward system-wide change. First, with respect to law's general attitude toward smaller scale economic change, it is important to remember that there are three possible answers that law might regularly give when economic actors seek its aid - stonewall change, support it indiscriminately, or slow it down somewhat.

Consider stonewalling. Law might choose to stonewall change and so give complete support to existing, and so entrenched, potentially politically powerful, economic interests. It is actually hard to find examples of such a response of law in the short twentieth century. Most are reasonably obscure; none merits mention in my story. Some instances can be supplied, however, such as the refusal to eliminate the role of the liquor wholesaler after changes in transportation made it plausible for many large producers to do so or the surprisingly long refusal of law to respond to the demands of the railroads to countenance elimination of a fireman on a train after diesel engines had replaced coal fired engines, or of the brakeman after the airbrake replaced the hand brake.

Next consider indiscriminate support. Law's response to smaller scale economic change might be to choose to favor change essentially indiscriminately and so ignore entrenched economic interests. This response of law is less remarkably rather difficult to find. However, the continuing effort of the Supreme Court to see that out-of-state mail order retailers do not have to pay the same local corporate and sales taxes as in-state retailers is a conspicuous exception. Oddly, the record on atomic power might be seen to provide a double example of this response as law first ignored the objections of the owners of existing coal-fired plants and then, when the political winds changed, ignored the interests of the owners of the new atomic power plants.

Consider finally a modest slowing of smaller scale change. Law might choose to work to retard change somewhat, but not to block it. Such a course 
of action would allow entrenched interests to work down their investments over time - to avoid the economist's seemingly heartless notion that sunk costs are sunk and so everyone should move on. Instead, such interests might recover at least a further part of their investments in monetary or personal capital, though it should be remembered that the risks faced by monetary capital can in theory, and at times in practice, be diversified much easier than those faced by personal capital. Equally importantly, by allowing a work down of sunk costs, law might buy off those political interests that would most stridently oppose change and, in doing so, might indirectly facilitate such change. This is actually the response most often evident in my story.

The best examples are relatively recent. The entire panoply of trade protection legislation has the structure of providing short-term respites for industries suffering from the effects of foreign competition, which, though always defended as providing the industry a chance to get its house in order, are all but invariably followed by a decline in the size of the industry in question. Here steel, textiles, and apparel are the classic cases. The same is true of the negotiation of bi- or multilateral "voluntary export restraints," programs whereby foreign countries agree to hold their company's exports down to some level experienced at an earlier time for a certain period of years. Here autos, steel, and again textiles (the multi-fiber agreements) are equally classic cases, where on expiration of the agreement, again justified as allowing the industry to get back on its feet, somehow the industry is smaller.

A second attitude disclosed in law's response to smaller scale economic change, one that clearly overlaps with its more general response to such change, can be seen by separately considering technological change, usually domestic in origin, and cost-driven change, usually foreign in origin. Examples of the former within the short twentieth century would be the extension of electric power to more and more homes; the development of commercial radio, television, and the personal computer; and the building of an effective airline passenger transportation network. This kind of change alters the way that Americans as consumers can live their lives, spend their time, envision their world; for them the change is visible but unproblematic. Examples of the latter would be the growth of textile manufacturing in Asia and Central America, of export-oriented automobile manufacturing in Europe and Asia, of similarly oriented electronics manufacturing in Asia, of natural resources production in the South America and the Mideast, or of computer programming skills in South Asia, instances where foreign producers possess a comparative cost advantage. With this kind of change lives remain much the same for most American consumers; the change is almost invisible and almost equally unproblematic. 
For domestic producers - both capital and labor $^{3}$ - of the same or of alternative goods or services, the matter is entirely different. It makes no difference to them whether change is technological or cost driven. These are the people identifiably harmed by change whatever its source; these are the people who will go to law for relief. The governmental response to the economic dislocations felt from both types of change might therefore be expected to be identical, given that the vast mass of consumers, the ostensible public of the public interest, is not obviously harmed by either. However, this turns out not to be so. Law will be more supportive of those whose lives are threatened by cost-driven change than of those who are threatened by technological change. Possibly, change in the way that Americans as consumers can live their lives, spend their time, envision their world makes it difficult to harness empathetic concern for those whose economic lives are harmed by this expansion in a consumer's surround. Definitely, the foreign invader is a more acceptable target than the domestic insurgent.

Good examples can be found of law's reaction to these two kinds of change. Consider first cost-driven change. In steel and autos, producers began by ignoring, then disparaging, the foreign-made goods, and finally ceding the lowest (and, on occasion, highest) margin products. When foreign producers were recognized as a real competitive threat to the investments of both capital and labor, a hue and cry went up to "save" the industry - in both cases an industry with complacent management and poor labor relations. Law repeatedly responded with temporary measures as the industry slowly shrunk in size, though in autos, after foreign manufacturers established domestic plants, claims for assistance went largely unanswered.

Textiles and apparel, including shoes, provide an interesting contrast, as does consumer electronics. Here the initial pattern of management behavior was roughly the same as steel and autos; the response of law was not.

${ }^{3}$ It is perhaps foolish for me to use the classic nineteenth-century language of capital and labor when writing about owners and workers in the short twentieth century. Capital comes in many varieties. Portfolio investment of varying kinds and sizes; productive physical assets of bewildering types and ages, owned in diverse ways by people in quite diverse circumstances; a similarly diverse range of real estate investments; owneroccupied homes and their contents; and of course the varying types of human capital might be considered a good start at a comprehensive listing, but nothing more. Similarly, labor ranges from the chronically unemployed through day laborers, union and non-union hourly workers in various settings, a similarly diverse group of salaried workers, to various freelance artisans and professionals who might be either workers or worker/owners. To attack this problem of understanding the contemporary structure of capital and labor would require an entirely separate article. As I am comfortable with the classic language because it ought to remind readers of significant questions of dependence and independence, I have chosen to maintain it. 
Textiles received the most continuous support - perhaps a function of the concentration of the industry in the Southeast, where Congressmen tend to serve long and reach high positions in party leadership and maybe also a recognition of the continuous, significant investments in manufacturing technology made by the industry. In consumer electronics, television manufacturers received some support, but by the time the Walkman reinvented the radio, domestic manufacturers had moved their own production offshore, law's support ceased, and the market was quickly dominated by foreign products. In apparel, domestic producers were largely at the mercy of the branded apparel marketers, particularly in women's wear. Here, little effective opposition to foreign incursions was mounted and so law's response was weakest, for the marketers quickly outsourced manufacture to the very areas where the threatening off-brand goods were originating.

The strength of these examples can be seen by comparing them to similar, but domestic, changes in technology. As the computer replaced the business machine, the electric replaced the manual typewriter, and the Xerox machine replaced various duplication processes from carbon paper through stencils to thermofax, competitors either adapted or died. Mostly they died. As television replaced radio, radio struggled, gave up live entertainment, and finally reinvented itself as a purveyor of recorded music. Foreign, costbased insurgencies brought forth a response when domestic, technologically driven ones did not. Capital is anything but xenophobic; this is not true of humans more generally.

A third attitude disclosed in law's response to smaller scale economic change, a pattern that again overlaps with the two previously considered, can be seen by examining a third type of economic change - system-wide change, boom or bust. Examples of this kind of change would be the great bust known as the Depression, the fifties and nineties booms and the Great Inflation. This kind of change tends to treat most, though never all, producers and consumers alike, as would the proverbial rising or falling tide. One might expect that the kind of economic change that is broadly felt would bring forth a similarly broad governmental response. However, system-wide change tends to bring forth governmental responses that are less uniform and broad based than narrow and targeted and are highly influenced by the political exigencies of the time.

The response of law to the Depression provides a well-known example. Although one can understand the New Deal's focus on agriculture and financial institutions, given the collapse in farm and stock prices and the raft of mortgage foreclosures and bank failures, other aspects of the Roosevelt administration's program are odd. Consider the relative exclusion of railroad aid. The high point of railroad domination of transportation was I9I6. After that point the quantity of railroad trackage declined and competition 
from inter-city bus lines became serious. During the Depression a large percentage of trackage was in receivership. Yet more of law's attention was paid to civil aviation, marginal for both passenger and cargo transportation, and to trucking as well.

Natural resources industries were treated no more uniformly. Coal mining, incredibly depressed from the decline in industrial production and the slow increase in residential and commercial oil heating; dependent on the railroads, both as a customer and a transporter; and possessed of a strong, if troubled, union tradition was lavished attention as a "sick" industry, even receiving its own separate New Deal statute and so its own Supreme Court declaration of unconstitutionality. Oil, where state-supported pro-rationing of production still could not avert a price decline, was similarly supported with federal legislation, though oil field and refinery workers were not comparably powerful and the industry was substantially less essential to the national economy, even given the growth of auto transportation, than the railroads. Other mining industries, as well as timber, all a matter of natural resources, were mostly ignored once the NRA fell apart, only to be declared unconstitutional thereafter anyway.

Autos and steel were possibly not as depressed as coal, all things being relative anyway, but were just as crucial to the economy and shared an equally troubled history of labor relations. They received no special attention, nor did any other manufacturing industry. And even agriculture was treated spottily. Grains were lavished with law's attention, but meat, poultry, and fish production were largely ignored. Cotton got included in crop subsidies, but not wool. Beans were ignored, and potatoes too, but rice, another starch, though hardly a centerpiece of the northern European culture that shaped this nation, received support as did sugar.

Now, all of these seeming anomalies can be explained by a combination of political and economic analysis. But the need for such is precisely the point. Despite broad-based economic distress, broad-based legislative support for the economy was not forthcoming.

The Great Inflation of the sixties and seventies equally illustrates this proposition. That law paid enormous attention to oil and natural gas production and pricing during these years is again easy to understand; the two oil price shocks and one embargo gained the attention of an auto-dependent nation in nothing flat. Similarly, currency and balance of payments questions were of daily concern given the abandonment of the gold standard and the much increased price of imported oil. But in a virtual repeat of the Depression, banking, securities, and agriculture all received major attention from law, as did commercial aviation and trucking. The big shift in law's attention was the railroads, a clear response to the Penn-Central bankruptcy that led to the formation of Conrail and Amtrak. Yet, except for steel and 
autos, manufacturing was again largely ignored, as was most of agriculture, except for the historically favored crops. Consumer prices received attention with Nixon's price control plan in the early seventies, but before and after that event, ordinary Americans were basically left to lump it.

The similarity of the pattern of economic sectors attended to and ignored forty years apart suggests certain durable features to law's instantiation of the politics of the economy. The continued political attention paid to the economic interests dependent on law for the definition of their powers, such as banking and securities, or dependent on law for their current economic value, such as agriculture or natural resources, is not surprising. At the same time such interest does not translate into narrow attainment of economic desires, much less stability. The success of the savings and loan industry in securing law's ministrations led to the industry's demise. And the banking industry prospered, if not beyond, at least up to, its wildest dreams, through a period in which its greatest legislative desire - the repeal of the GlassSteagall Act - was beyond its reach.

In some ways, more important than the durability of law's response to the politics of economy is the evidence that both the Depression and the Great Inflation provide of law's limited range of attention where matters of system-wide economic change are concerned. The production, distribution, and consumption of manufactured goods, whether industrial or consumer, seemingly the engine of economic life, were (except for the National Recovery Administration) largely ignored by law in cases of cyclical economic change. Perhaps these activities are too diffuse to bring politically organized attention; perhaps they are too far removed from law's regular concerns, except as a purchaser of military supplies or construction services; perhaps they are just too close to the heart of a capitalist economy.

\section{Three Contexts for Law's Response to Smaller Scale Economic Change}

In addition to the three discernible attitudes disclosed in law's response to smaller scale economic change, I can profitably examine three particular contexts for that response - infrastructural investment, regulatory investments, and social circumstances. Consider first infrastructural investments. One of the great, unheralded, and almost invisible legal inventions prominent in the short twentieth century is the public authority, an entity functionally similar to the eighteenth-century corporation. Originally it was nothing but a vehicle for evading state constitutional restrictions on state and local debt and still, of course, functions as such. A legal entity is formally established as separate from its parent governmental unit, given building and/or purchasing and, most importantly, bonding authority. It is then set on its way to pursue the public good. Under the fiction that, as it is separate 
from its parental authority, it is not bound by constitutional restrictions on the actions of the establishing entity, normally its objective is engaging in building or buying something using borrowed funds, the repayment of which is secured by some stream of revenue that the built or purchased asset is supposed to throw off.

The best known of such entities established by a state or local government is the Triborough Bridge and Tunnel Authority, the centerpiece of Robert Moses' New York empire. But such authorities also build and operate toll roads, canals, harbors, airports, transit systems, hospitals, dams and their power plants, convention centers, and sports arenas; they also build and then lease public housing, state universities and their dormitories, and defense plants. Creating such entities removes them somewhat from the rough and tumble of legislative and executive politics and even where debt restrictions are not constitutional, as is the case with the federal government, hides their debt a bit from public scrutiny.

Public authorities are regularly established for the purpose of providing infrastructure investment that it is hoped will bring positive economic results for the relevant community. They are thus classic examples of law working either to rehabilitate deteriorating facilities or to build new ones and thus either to retard or to facilitate change. Three federally established public authorities - Fannie Mae, Freddie Mac, and Ginnie Mae - figure reasonably large in my story; two others, the Tennessee Valley Authority and the Bonneville Power Authority, are also well known. All five were built to facilitate change; they and many others have served that objective remarkably well, if not exactly in the way initially envisioned.

In contrast, most attempts to use public authorities to retard change, for example by rehabilitating decayed canal or port structures with the objective of bringing traffic back to the area, have been notable failures. Buffalo provides a good, if obscure, example. In the early fifties Buffalo ceased to be an important place for the trans-shipment of grain for flour milling and export as the mills were moved closer to Midwestern grain markets and as barge transit down the Mississippi to the redeveloped port at New Orleans became an increasingly feasible alternative to the older route to East Coast ports via freighter through the Great Lakes and rail thereafter. An increasingly decrepit and inactive waterfront mirrored the decline of Buffalo's milling and trans-shipment activities, and so, a port authority was created to make the port more attractive. Soon thereafter the failure of the local surface transportation company brought the change of the port authority into a more general transportation authority that took over airport operations as well. Forty years later the result of these actions by law is instructive: a modest, but cheerful airport survives on landing fees; a surprisingly pleasant local transportation system limps along, despite 
significant grant-based investment, as ridership decline follows population decline; and the port is still sad to see. It can't possibly be rehabilitated because there is little reason for anyone to use it as lake freighter-dependent industry slowly disappears. So, almost no fee income is generated that might fund rehabilitation.

A second context for examining law's response to smaller scale economic change is in threats to regulatory investments, characteristically made as part of the legacy of various New Deal economic recovery programs. Tied to associationalism as they were, the New Deal economic programs tended to think of business relationships as static and so favored dividing markets in ways that, although they did not guarantee that profits would be made, did allow all existing participants to compete in gentlemanly ways within industry segments while keeping potential competitors happy with similarly protected hunks of the overall economic "turf." This policy is most obviously evident in the banking, insurance, and securities industries. It is also prominent in communications and transportation and can be seen in agricultural programs as well.

The associationalist assumptions underlying economic policies in areas such as these create particular problems when the affected industries find that economic change, sometimes technological, at other times cost driven, undermines the assumed static structure of competition. This is because over time this structure becomes built into the valuation of existing investments and leads to making further investments whose value is similarly dependent on the existing industry structure. How to unravel these investments fairly has bedeviled law for the past half-century. Two examples should suffice.

American agricultural policy, like the postwar agricultural policy of other major European and Asian industrial states, is an incredible mess. Here, the New Deal agricultural policy trio of ascertainably rational but practically ineffective production controls - predicated on acreage under cultivation rather than total yield, crop subsidies that sustained the most depressed segments of the increasingly irrelevant agricultural past, and modest soil conservation programs - has persisted despite generations of otherwise withering critique and through a period of extraordinary declines in the farm population and a technologically driven explosion in per acre productivity derived from increased use of expensive fertilizers, farm machinery, and hybrid crops. Although it is surely plausible that were the Senate elected in proportion to population, agricultural subsidies would be withdrawn, it seems to me that the continuing program less reflects the constitutional rule giving each state, regardless of population, two senators than it does the difficulty of withdrawing subsidies once they have been built into the fabric of economic assumptions that are farm valuation. 
To withdraw subsidies imperils farm income, which imperils farm mortgages (and so ownership), which imperils farm mortgage lenders, a narrow, local branch of lending. Thus, what may be a rational economic plan for ending subsidies that in the long run may benefit agriculture and the entire national economy creates short-run problems that are extremely painful and threaten the owners of the existing farms, agricultural cooperatives, and financial institutions as well as farm communities, including not just farm implement dealers and feed, seed, and chemical sellers, but also auto dealers, grocers, schools, churches, and restaurants. Lacking the political will to buy existing beneficiaries out of their subsidies through a program of capital grants, and already having extended governmental guarantees under the program of mortgage insurance offered by Farmer Mac, the only politically palatable solution is hobbling along under an endlessly adjusted, obviously defective program. ${ }^{4}$

The tangled story of the transformation of the segmented worlds of banking, insurance, and securities provides a modest counterpoint to the difficulties with agricultural policy. The continuing breakdown of the segmented structure of these industries can be told either as a case of domestic insurgency, as each of these industries tried to escape from the straitjacket that was established during the Depression in the name of restoring confidence in the financial system, or as a case of a foreign insurgency, as the availability of more attractive foreign investments over times led to the unraveling of the New Deal financial order. And yet, rather than do nothing, as if the insurgent were domestic, or provide transitional support, as if the insurgent were foreign, law's response in almost all cases was to expand the powers of the institution whose separate protected sphere was threatened by financial innovation. ${ }^{5}$

Here again the long-standing set of economic controls created a set of investments whose value was significantly determined by the structure of regulation. Trying, though not necessarily succeeding, to maintain relative parity between industry segments was a response that served to protect the relative, though hardly the absolute, value of these regulatorily based investments. Thus, attempts to alter the income tax treatment of mutual as against stock insurance companies, where mutuals possessed a significant advantage, were never successful, but a change in the investment powers of one regularly led to a change in the investment powers of the other. Similarly, in the segmented world of banking, branching by commercial

${ }^{4}$ The recent case of tobacco acreage allotments is hardly an example to the contrary, for it took years of health concerns, unlikely to be reproduced elsewhere in agriculture, to overcome political opposition to such a "bailout."

${ }^{5}$ The case of the deregulation of interstate trucking under the Motor Carriers Act is to the contrary. I cannot explain why. 
and by mutual savings banks grew approximately apace, though in the former case most often by merger and in the latter case because of the legal form, most often by building new offices. The same is true of change across industry segments. Banks became able to sell securities only when securities firms were able to offer bank-like services through money market "wrap" accounts that allowed check-writing privileges.

Of course, the most notorious examples of such attempts to maintain the relative value of regulatorily founded investments is the interaction between commercial banks and savings and loan associations - the savings and loan crisis, discussed previously. It began with the development of money market funds in the securities industry that drew deposits from a banking industry that was limited by law as to the interest it could pay on deposits. Eliminating these limits, the initial response, exposed the fact that the greater range of loans that commercial banks could enter into meant that they could earn more interest than could savings and loans that were limited to making residential mortgage loans. And so, these restrictions were lifted. An unpleasant cascade of events followed such well-intentioned actions.

A third context for examining law's response to smaller scale change can be identified by emphasizing certain social regularities in law's actions. Indeed, some would say that law nearly always allows the capitalists to win. This notion, coming largely out of labor relations where it has some real bite, is more difficult to support in circumstances where law confronts economic change more generally. In such circumstances capital and labor, employers and employees, stand on both sides of the issue that law faces favor old capital and labor or new. Each has a claim to law's attention the old, because of ties to the existing community; the new, because of its asserted but unprovable place in the economic future.

As is evident from my story of economic change and from the preceding analysis, at least in the short twentieth century, law has tended to favor new capital, and derivatively new labor, because dreams are easier to spin than realities are to dress up. At times law does this by providing some transitional support for the past while facilitating a seemingly brighter future. At other times, not even transitional support is provided. However, there is a regularity, an identifiable pattern of winners and losers among those whose lives and fortunes are altered by smaller scale economic change. Not surprisingly, most often law is more effective when offering transitional support to capital than to labor.

Examples are reasonably easy to identify. Consider, again, autos and steel. In both of these industries capital and labor received approximately the same protection from foreign competition. Indeed, labor arguably received more favorable treatment in that pension guarantee legislation extends protection to human capital that is unavailable to investment capital. Yet, there is no 
great record of poor, demoralized stockholders in either the auto or steel industries as there is of poor, demoralized employees in those industries who never made it to retirement before their jobs disappeared. The reason is simple. The time horizon of capital, especially financial capital, but also bricks and mortar capital, is shorter that that of labor. Moreover, capital can diversify more readily to reduce risk. A working life is forty to fifty years and retraining to build new human capital investments becomes increasingly difficult after fifteen to twenty of those years. In contrast, a long horizon for the recovery of a capital investment is surely those same fifteen and twenty years, at which point dis- and re-investment are substantially easier. And over the last twenty years of the short twentieth century, the mean time horizon for capital recovery has surely shortened. Of course, capital losses in the early years before recovery is had are common, indeed more common than long-term recovery. And everyone who studies industry carefully has discovered stories of capital loss after long- term recovery that are every bit as devastating to the individual entrepreneur as are similar job losses to individual laborers. But in many, perhaps, most cases, capital has more accumulated assets to fall back on, and so equal treatment of human capital is anything but.

\section{A MODEST CONCLUSION}

How then might the complex relationship between law and economic change, the change from an associationalist to an impatient economy, in the short twentieth century be summarized? Although law contributes little to such large-scale change, again the great silent background of law that structures economic relations needs to be emphasized. Common assumptions about economic life under capitalism that are formalized as the rules of contract, tort, and property do their silent work. And as the winds of change blow and calm, so too do the institutions of law, including those that are commonly described as political, working as they do modestly to speed up change, to augment the prevailing winds.

What then of the more active work of law, work carried on with respect to smaller scale change? Description of law's response to the winds of change in terms of the great battle between laissez-faire and regulation that figures so prominently in the political rhetoric of both the left and the right in America is clearly inappropriate. In general, law favors neither position, but most commonly, but rather unsystematically, attempts to facilitate change by modestly retarding it. As it does so, it tends to be willing to respond more readily to economic harm suffered at the hands of foreign "invaders" of the allegedly national economic "turf" than of the domestic invaders of an individual industry's "turf." It pays more attention to segments of the 
economy whose powers, or the value of whose investments, are dependent on law. Overall, it is more solicitous of new capital and labor than old, but even here, more to the harms suffered by capital than by labor. None of this ought to be surprising. Law, like other human institutions, works most often by half-steps that affirm the past while moving cautiously into the present and hiding from the future. Americans, like most humans, are notoriously xenophobic, however much they love their imported DVD players. And the United States is a capitalist, though hardly a free market capitalist, and definitely not a social democratic, economy.

\section{CODA}

Readers have asked that I explain more precisely what I mean by "law" and so its relationship to "society" and "the/an economy," as well as to flesh out the metaphor of the "loosely woven fabric." I can do none of these things, but my readers deserve an explanation for that fact.

Karl Llewellyn was fond of speaking of "law/government" as a way of eliding the separation of "law" from "politics," a separation that he believed to be unhelpful for analysis. I would be comfortable following his lead by eliding my definitional problems through the use of the cognates "law/society" and "law/economy," as I firmly believe that neither dichotomy is useful for understanding the subject I am trying to explicate (or any other subject either.) Unfortunately, I have learned that readers do not always accept such neologisms, as the soundless sinking of Llewellyn's makes clear. I am fully aware that his academic profile was far higher than mine. So, I have largely resisted doing what would be comfortable for me and have decided to work within the only language that I have, a language in which "law" by definition is neither "the/an economy" or "society," no matter how much I may wish them to be seen as deeply, inextricably intertwined.

In the vain attempt to avoid this aspect of "the prison-house of language," I have chosen to leave "law" and "an economy" but weakly demarcated (see italicized explanations offered at the outset of this chapter). I do not use "society" at all and leave "the economy" to a usage close to the rise and fall of the level of economic activity as well as the order and chaos experienced by participants in economic activity. In doing so, I have been able to focus on change in the form of, which is to say our understanding of, capitalism over time. By thus cabining usage I can present "law" and "an economy" as inseparable, except when analysis in the English language makes it impossible to avoid a usage that might imply to the contrary.

I have tried to bridge the gap between my understanding of the relationship between law and the/an economy and the usage available to me with a metaphor of the "loosely woven fabric." I like this metaphor because, if 
one pulls at too many threads in a loosely woven fabric, it rather quickly becomes a pile of thread and not a fabric at all. It is for this reason that I have not developed this metaphor extensively. Doing so would turn it into a pile of separate but entangled observations about "law" and "the/an economy" and it is just such a jumble that the metaphor is designed to avoid.

I hope that readers have been able to be patient with the locutions I have adopted. Until we have a language that allows for the suppression of dichotomies such as law and politics, law and society, law and economy, such is the best that this writer can do. 